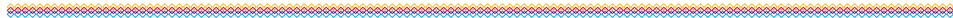

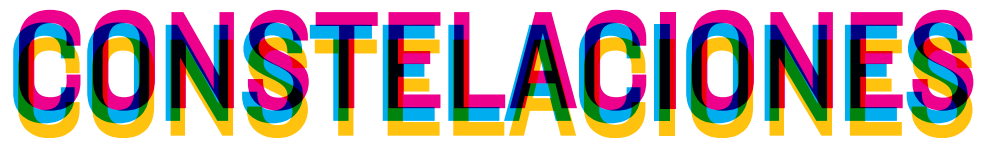

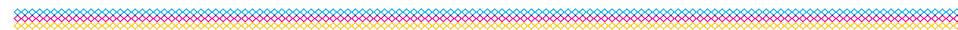


CONSTELACIONES nº6, mayo 2018

Revista de Arquitectura de la Universidad CEU San Pablo

Architecture Magazine of CEU San Pablo University

Periodicidad anual

Annual periodicity

COMITÉ DE REDACCIÓN EDITORIAL COMMITTEE

\section{Dirección Directors}

Juan García Millán

Santiago de Molina

Jefa de Redacción Editor in Chief

Covadonga Lorenzo Cueva

Secretario de Redacción Editorial Clerk

Rodrigo Núñez Carrasco

Maquetación y producción Design and production

Clara Martínez-Conde Rubio

Julia Ruiz-Cabello Subiela

Responsable Web Web Page Manager

María Isabel Castilla Heredia

Diseño Original Original Design

Juan Roldán Martín

\section{CONSEJO EDITORIAL EDITORIAL BOARD}

Beatriz Colomina. School of Architecture, Princeton University, New Jersey

Carmen Díez Medina. Escuela de Ingeniería y Arquitectura, Universidad de Zaragoza

María Antonia Frías Sargadoy. Escuela Técnica Superior de Arquitectura, Universidad de Navarra

Juan Miguel Hernández Léon. Escuela Técnica Superior de Arquitectura, Universidad Politécnica de Madrid Juan José Lahuerta Alsina. Escuela Técnica Superior de Arquitectura, Universidad Politécnica de Cataluña, Barcelona Eduardo Leira Sánchez. Ex director del Plan General de Ordenación Urbana, Madrid

Joaquín Medina Wamburg. Facultad de Aquitectura Diseño y Urbanismo, Universidad de Buenos Aires

Zaida Muxí Martínez. Escuela Técnica Superior de Arquitectura, Universidad Politécnica de Cataluña, Barcelona José Joaquín Parra Bañón. Escuela Técnica Superior de Arquitectura, Universidad de Sevilla

Víctor Pérez Escolano. Escuela Técnica Superior de Arquitectura, Universidad de Sevilla

Fernando Pérez Oyarzún. Escuela de Arquitectura y Diseño, Pontificia Universidad Católica, Santiago de Chile

Judith Sheine. School of Architecture and Allied Arts, University of Oregon, Portland

Andrés Walliser Martínez. Global Design, New York University, Nueva York

ISSN 2340-177X

Depósito legal M-13872-2013

(c) de los textos, sus autores

(c) de las imágenes autorizadas

(c) Revista Constelaciones

๑) Escuela Politécnica Superior, Universidad CEU San Pablo

Universidad CEU San Pablo

Escuela Politécnica Superior

Urbanización Montepríncipe, s/n

Alcorcón, 28925. Madrid (España)

constelaciones@eps.ceu.es

www.uspceu.es

www.revistaconstelaciones.wordpress.com

Edición Edition

Fundación Universitaria San Pablo CEU

Madrid, España

Impresión Printing

VA Impresores

Impreso en España Printed in Spain

Distribución Distribution

CEU Ediciones

\author{
INDEXACIÓN INDEXING \\ Índices Index \\ Latindex \\ Avery Index \\ ErihPlus \\ MIAR
}

Bases de datos Data bases

Dialnet

Índices en evaluación Evaluation Index

Web of Science

Scopus

Dulcinea

EBSCO

Sherpa Romeo

Los textos que componen Constelaciones se obtienen mediante convocatoria pública. Para que los trabajos recibidos entren en el proceso de selección de los artículos a publicar deben ser trabajos originales no publicados anteriormene, con una extensión recomendada de 3.000 palabras, título, resumen (un máximo de 150 palabras) y palabras clave (un mínimo de cuatro palabras), en español y en inglés. Tras haber cumplido estos requisitos (y los correspondientes incluidos en las normas editoriales de la revista, disponibles para consulta en formato digital desde el comienzo de la convocatoria), tiene lugar un proceso de revisión y evaluación de los artículos previa aceptación de los mismos para su publicación. Para acometer dicho proceso, y con el fin de asegurar la calidad de los contenidos, la revista Constelaciones recurre a evaluadores externos a la institución editora y anónimos (cada artículo es evaluado por dos de ellos) encargados de someter a crítica los mismos. Todos los artículos de investigación publicados en esta revista han pasado por dicho proceso. La recepción de artículos se extendió hasta el 30 de septiembre de 2017. Texts included in Constelaciones are obtained by public announcement. Only original papers that have not been previously published will be included in the process of selection of articles. They should not exceed 3.000 words and should include a title, an abstract (no more than 150 words) and keywords (a minimum of four words), in Spanish and English. After having fulfilled these requirements (and those included in magazine editorial standards, available for consultation from the beginning of the Call for Papers), occurs a process of review and evaluation of articles upon acceptance of them for publication. To undertake this process, and in order to ensure the quality of the contents, Constelaciones turns to external and anonymous evaluators to the institution (each article is evaluated by two of them) responsible for the critic. All the articles published in this journal have undergone this process. The deadline for reception was extended until September 30, 2017.

Todos los derechos reservados. Esta publicación no puede ser reproducida, ni en todo ni en parte, ni registrada, ni transmitida, ni almacenada en ninguna forma ni por ningún medio, sin la autorización previa y por escrito del equipo editorial. En este número se han utilizado algunas imágenes de las que no se ha podido identificar al propietario de los derechos. En estos casos hemos entendido que las imágenes son de libre uso. En caso de identificar alguna de estas imágenes como propia, por favor, póngase en contacto con la redacción de Constelaciones. Los criterios expuestos en los diversos artículos de la revista son responsabilidad exclusiva de sus autores y no reflejan necesariamente los que pueda tener el equipo editoral. El equipo editorial de la revista no se responsabiliza de devolver la información enviada a la redacción a no ser que se le solicite expresamente. All rights reserved. This publication cannot be reproduced, in whole or in part, nor registered, transmitted or stored in any form or by any means, without the written permission of the Editorial team, In this issue some images were used without knowing the owner of the rights. In these cases, we have understood that the images are free of use. In case you identify shared by the editors of this journal. The publisher don't take responsibility for returning submitted material which is not expressly requested. 


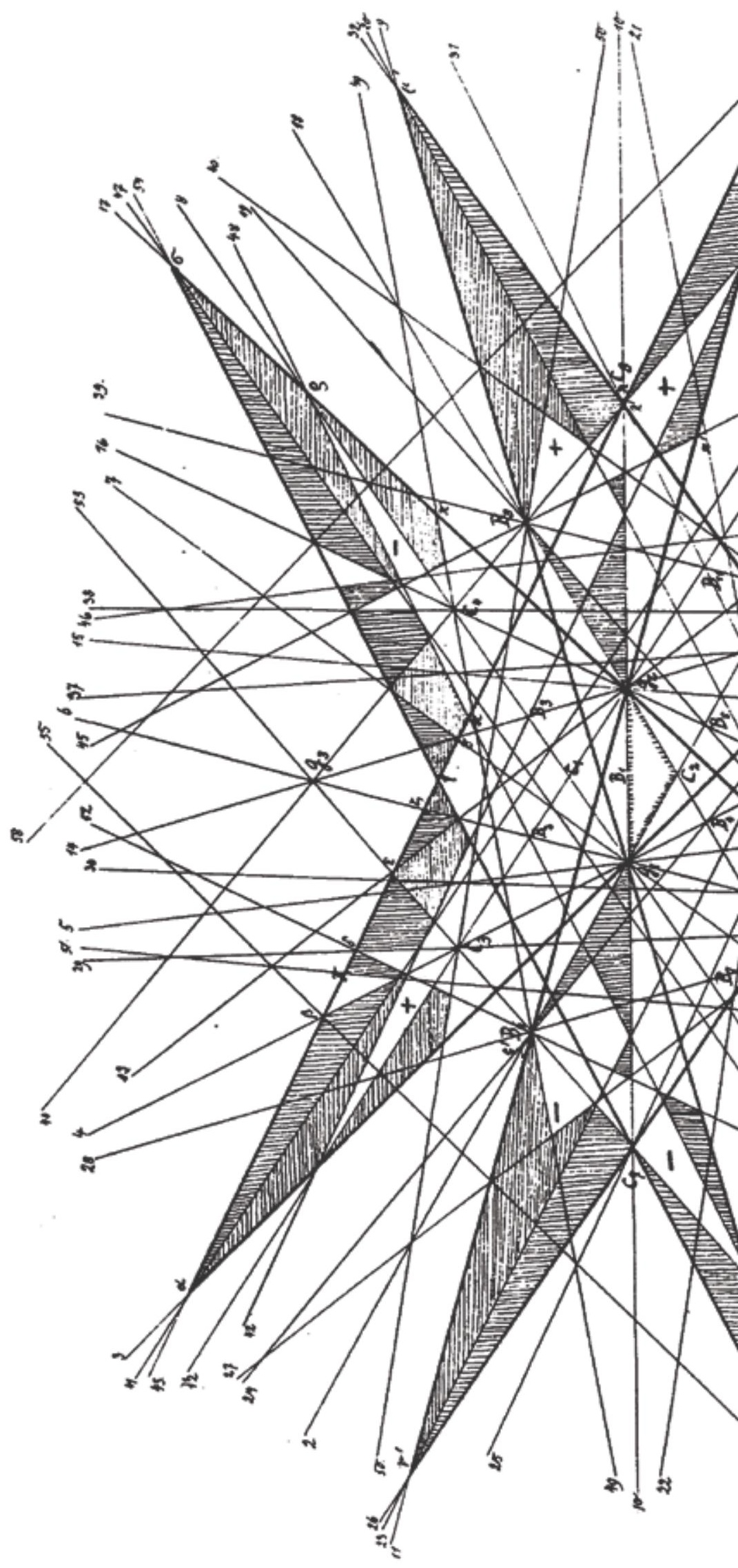




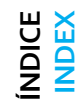

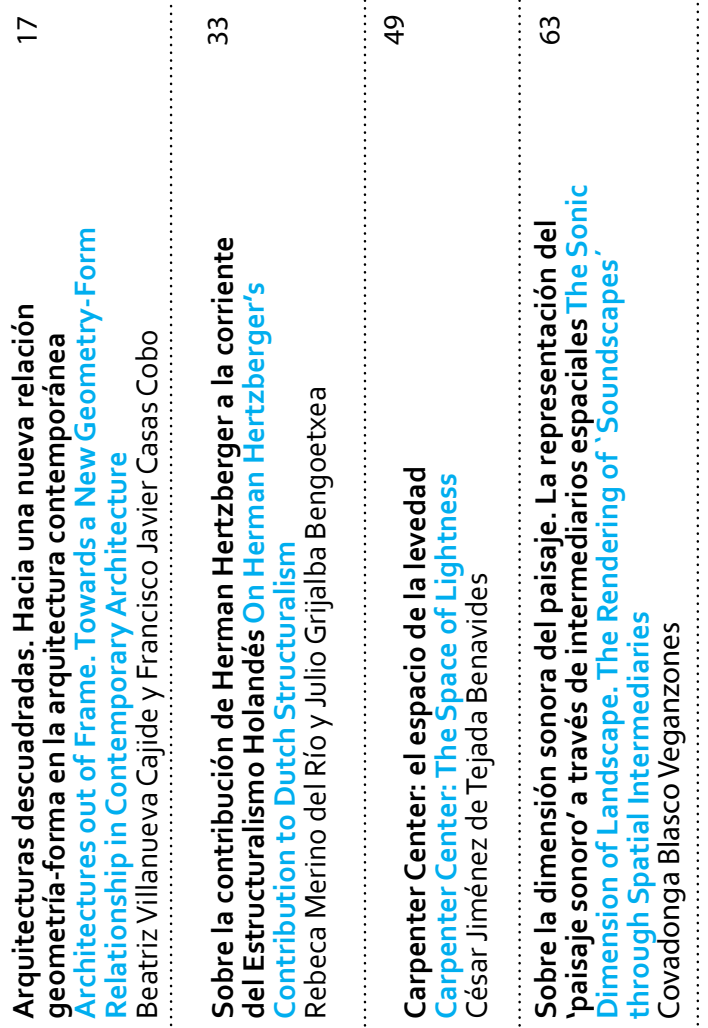

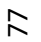

ต

$\leftleftarrows$

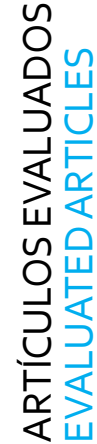

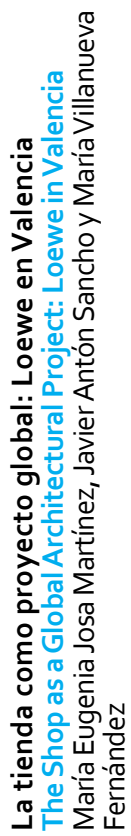

윰 可

틈응

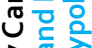

울을

I0

율

동

능

잉이

용요

ब雨

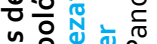

은음

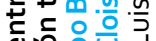

넌은 을겅

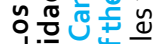

능뭉ㅎㅇㅇㅇㅇ

荇

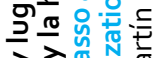

入入⿻

준

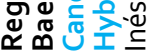
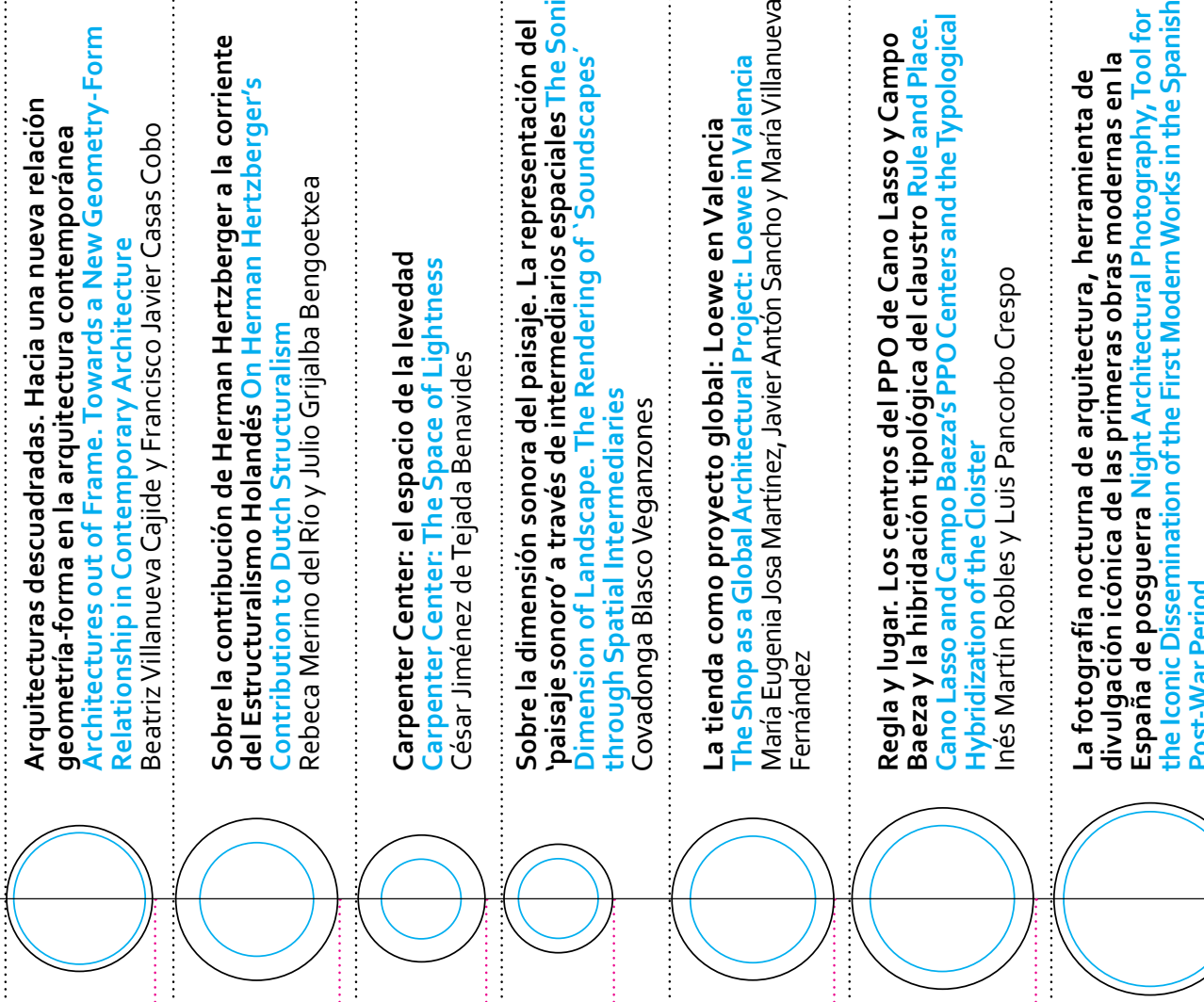

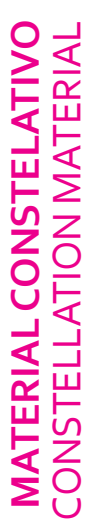

岂㟧

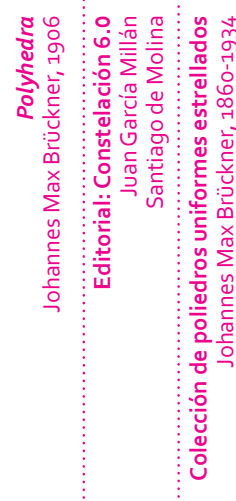

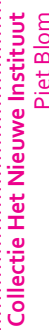
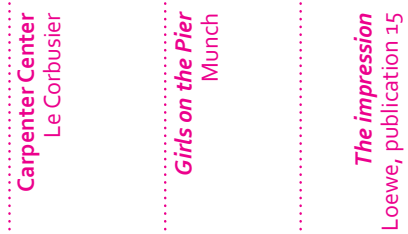

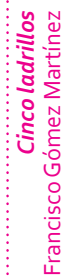

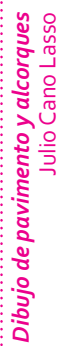

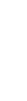

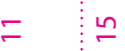

$\bar{m}$

ร

ธ

옹 


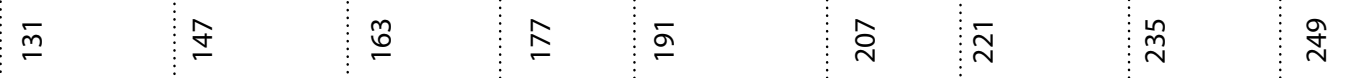

ह단

竞:

을 응

$\frac{\pi}{2} \cup$

을

约

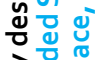

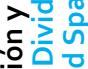

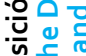

负

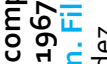

중

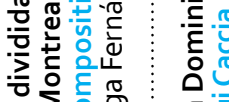

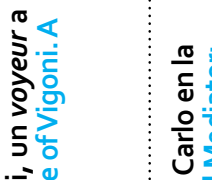

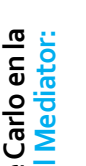

हें

ดั ชั

은 흥영

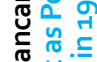

ชั่

ए

ธิ่

过 벙

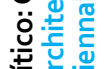

능는

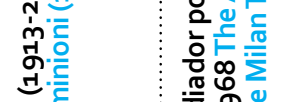

ชั0

हूष

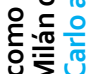

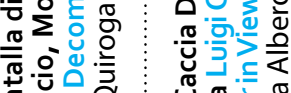

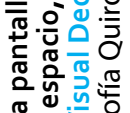

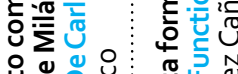

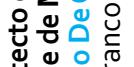

껀

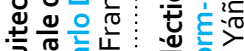

:

혼든 은

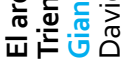

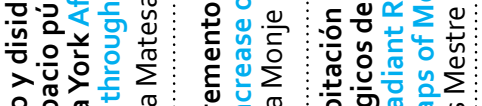

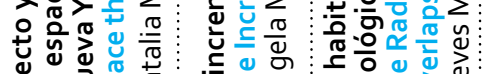

选守之光艺

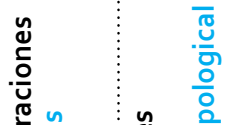

는 흔

กำ $\frac{1}{0} \div$

ถั

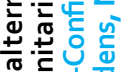

入ว 일

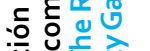

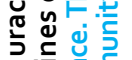

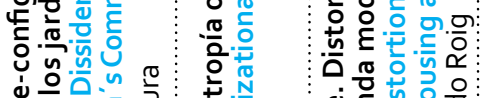

๙

.ํำ $\stackrel{0}{0}$

난.

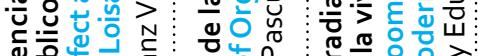

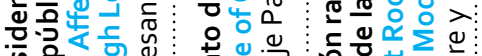

능

త $>\boldsymbol{>}$

ง๋

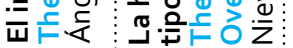
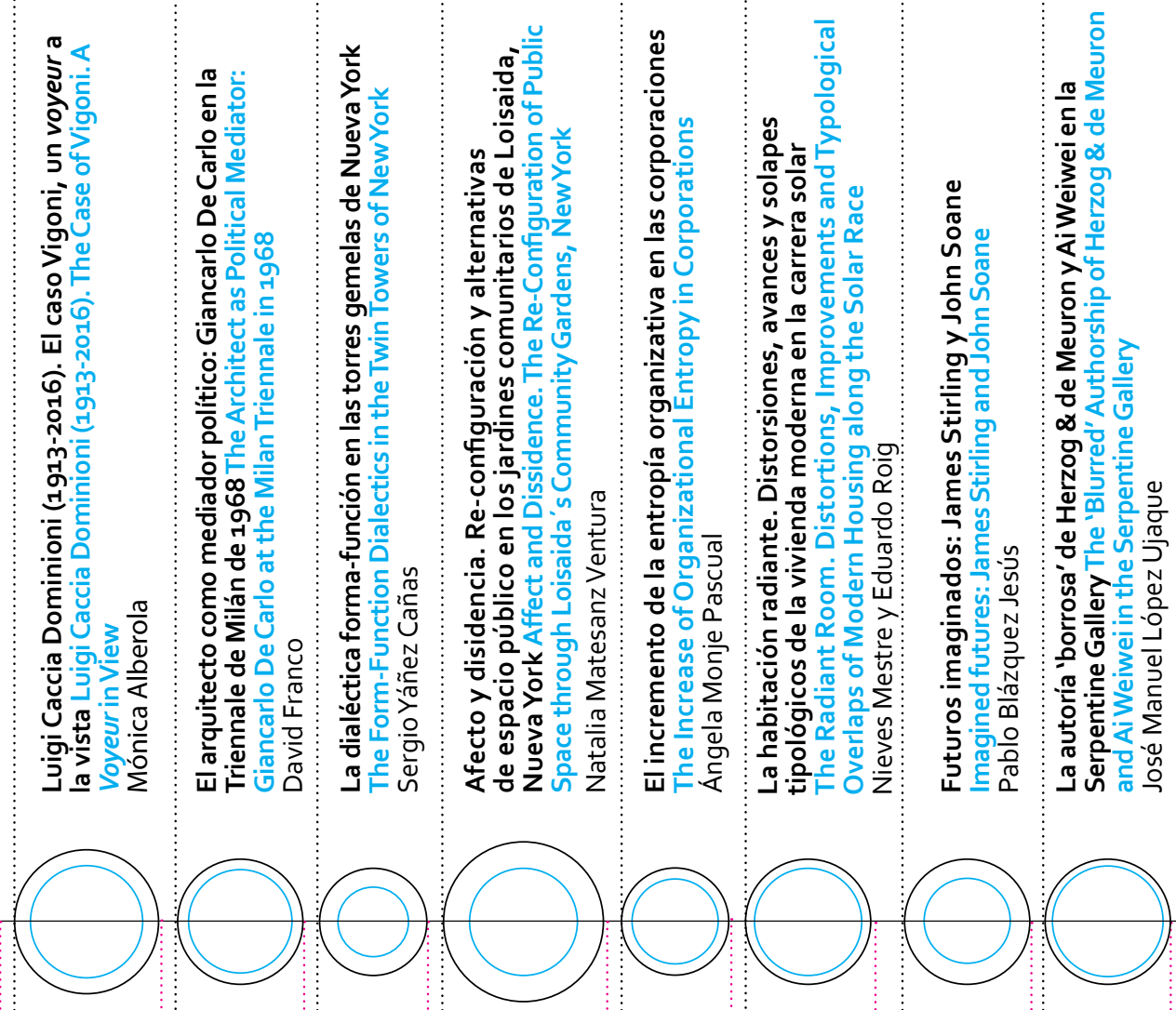

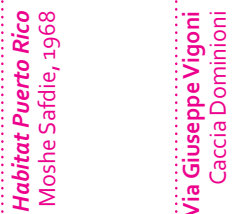

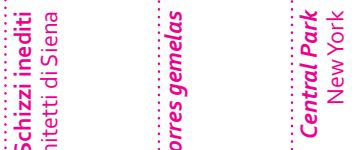

$\sum_{2}^{2}$

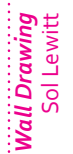

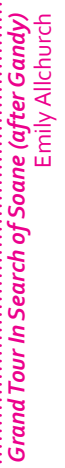

ำ

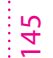

$\stackrel{\circ}{\stackrel{n}{2}}$

$\infty$

ํํำ

$\stackrel{N}{\sim}$

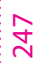

융 గ 


\section{I itshitingenfabriek}

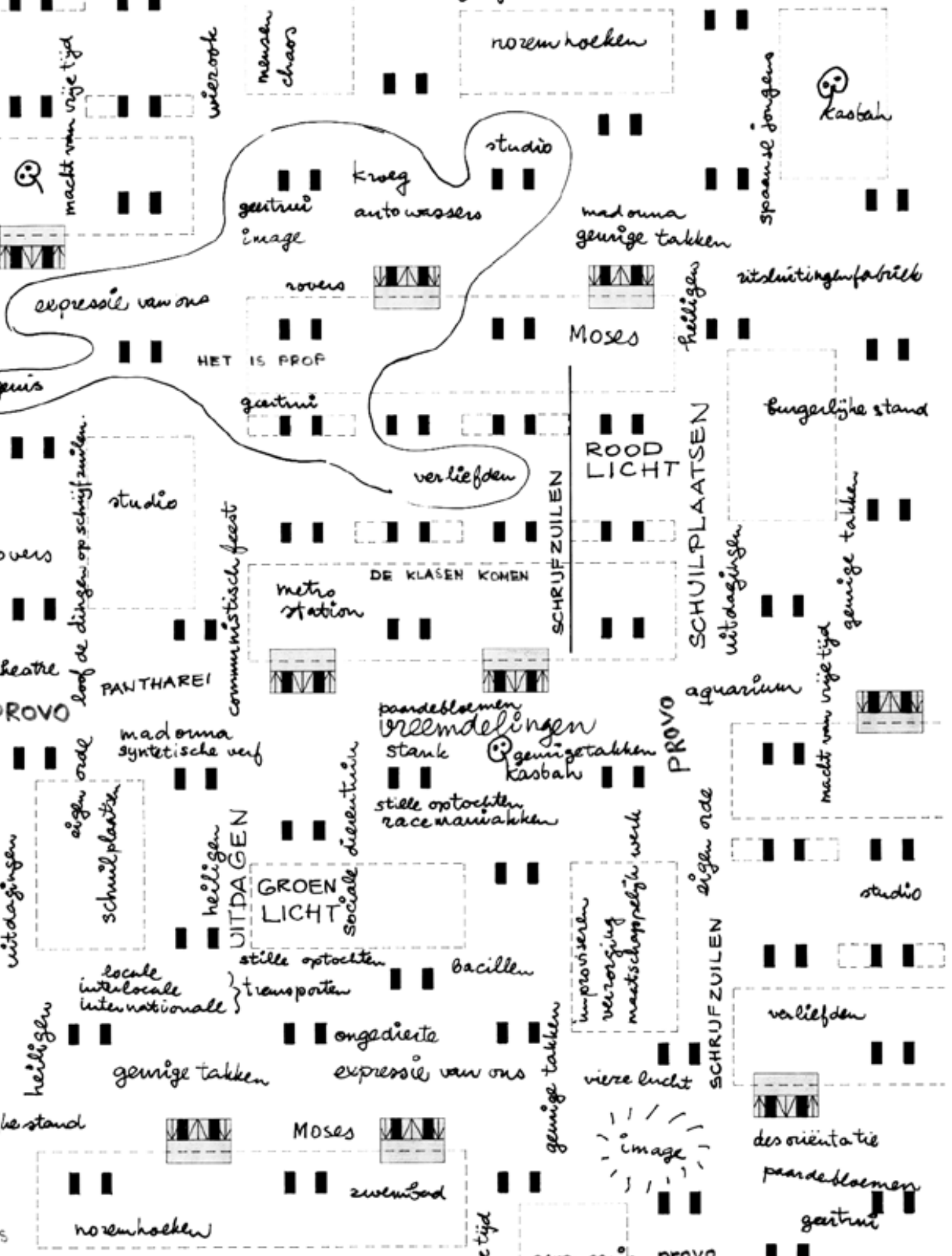




\title{
Sobre la contribución de Herman Hertzberger a la corriente del Estructuralismo Holandés
}

\section{On Herman Hertzberger's Contribution to Dutch} Structuralism

\author{
Rebeca Merino del Río, Julio Grijalba Bengoetxea \\ Escuela Técnica Superior de Arquitectura, Universidad de Valladolid \\ Traducción Translation Rebeca Merino del Río
}

\section{Palabras clave Keywords}

Estructuralismo Holandés, controversia, Herman Hertzberger, ciencias sociales, lingüística, dimensión humana.

Dutch Structuralism, controversy, Herman Hertzberger, social sciences, influences, linguistics, human dimension.

\section{Resumen}

En la década de los sesenta, el trabajo de un conjunto de arquitectos neerlandeses se engloba bajo la terminología de Estructuralismo Holandés. La falta de una cohesión interna, así como las divergencias entre los distintos autores, han dado lugar a una lectura de su obra desde una perspectiva puramente arquitectónica, quedando relegados así, aspectos característicos de las ciencias sociales que se consideran de vital importancia para la correcta comprensión de algunos de los edificios y escritos. El impulso que este tema ha recibido en los últimos años se ha enfocado estrictamente en la vertiente compositiva, por lo que se considera imprescindible una revisión de los principios teóricos e influencias, con marcado carácter transversal, que siente los cimientos para futuras evaluaciones. Para ello, se tomará como referencia la obra escrita de uno de estos autores, Herman Hertzberger, que resulta clave por lo propositivo de sus aseveraciones y razonamientos. Un estudio comparativo de las teorías estructuralistas desarrolladas en otros campos, como la lingüística o la antropología, y los conceptos empleados por Hertzberger, no sólo demuestra la correspondencia real, sino también nos permite evaluar en qué medida el arquitecto neerlandés contribuyó al estructuralismo holandés.

\section{Abstract}

In the sixties, several Netherlander architects produced work identified as Dutch Structuralism. A lack of internal cohesion and divergences among the different authors, have led to a reading of their work from a more purely architectural perspective, with some of the aspects that are characteristic of the social sciences, being relegated to a less relevant position. Those aspects, are however, considered of the utmost importance to correctly comprehend some of the buildings and writings. Since the boost that this subject has received in the last years has been strictly focused on the compositional side, it is considered imperative that a transversal-nature review of the theoretical principles and influences is made, to provide the basis for future assessments. For that purpose, Herman Hertzberger's written work is taken as a reference, whose results are key because of his propositional asseverations and reasoning. A comparative study of the structuralist theories developed in other fields, such as linguistics or anthropology, and the concepts employed by Hertzberger, not only demonstrates the actual correspondence, but also allows us to assess to what extent he contributed to Dutch Structuralism. 
Estructuralismo: polémica y problemática asociada a la elección de un término. La denominada corriente del Estructuralismo Holandés engloba la obra de una serie de arquitectos que, desde los años sesenta, promovieron una arquitectura principalmente orientada a dar respuesta a las grandes masas de usuarios y las nuevas tipologías arquitectónicas surgidas al final de la Segunda Guerra Mundial, en un contexto marcado por la mutación del sistema capitalista. Destacan las obras de arquitectos como Piet Blom, John Habraken, Joop Hardy, Herman Hertzberger, Joop van Stigt, e incluso Aldo van Eyck. (Figs. 1 y 2) Sin embargo, y de acuerdo con las últimas declaraciones realizadas por Herman Hertzberger, "nunca existió una conciencia de formar parte de un grupo organizado", (1) como sí ocurriera con el Team x. La prácticamente inexistente producción teórica de los autores, así como la fuerza que adquieren los criterios puramente arquitectónicos en la crítica de los trabajos, dificultan una lectura más allá de temas estéticos, constructivos o funcionales. Los deliberados intentos de Herman Hertzberger por incluir términos y referencias procedentes de otras disciplinas, que pretenden abrir una nueva vía de comprensión de la arquitectura, han sido desatendidos durante años, a pesar de las actuales tentativas de retomar su
Fig. 1. Blom, Piet: Cafetería universitaria De Mensa, Twente, septiembre de 1967. Piet Blom's Archive, Rijksarchief voor Nederlandse Architectuur en Stedenbouw, Het Nieuwe Instituut.

Fig. 2. Van Stigt, Joop: Propuesta para el Prix de Rome, 1962. Joop van Stigt's Archive, Rijksarchief voor Nederlandse Architectuur en Stedenbouw, Het Nieuwe Instituut.
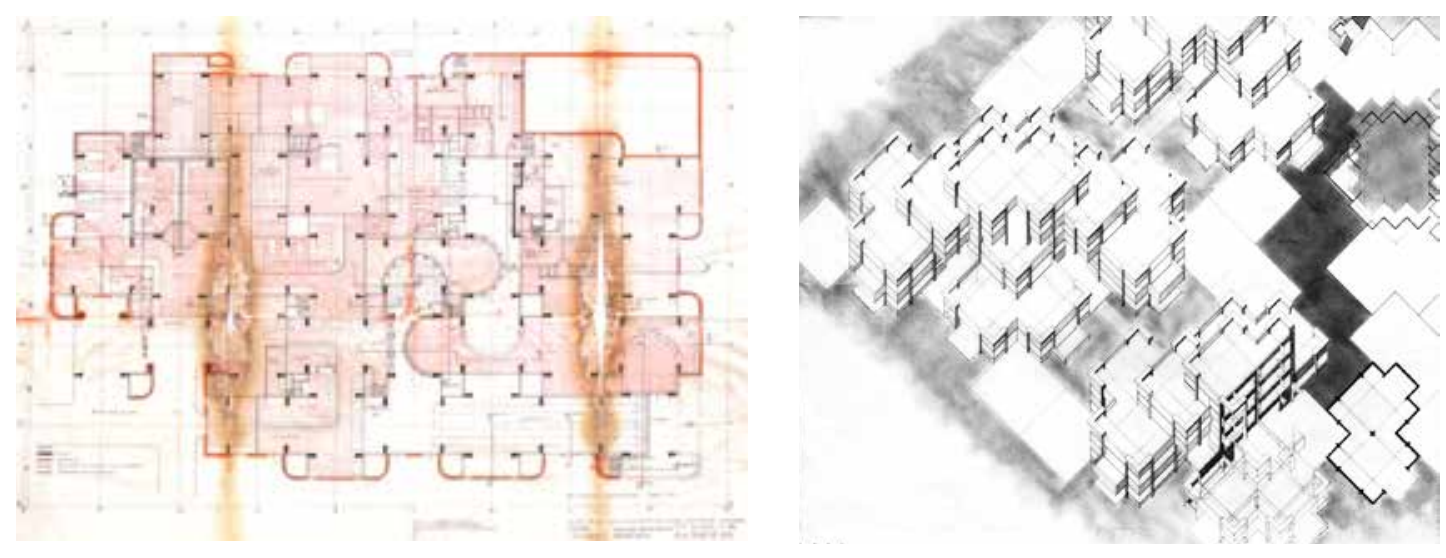

Structuralism: Controversy and Problems Concerning the Choice of a Term. The so-called Dutch Structuralism comprises the oeuvre of a series of architects that, since the sixties, promoted an architecture mainly focused on giving response to the great number of users and the new architectural typologies starting to be used at the end of the Second World War, in a context characterised by the evolution of the capitalist system. The works of Piet Blom, John Habraken, Joop Hardy, Herman Hertzberger, Joop van Stigt, or even Aldo van Eyck, stand out among them. (Figs. 1 \& 2) However, and according to recent statements issued by Herman Hertzberger, there was never "an awareness of being part of an organised group", (1) the opposite to what happened with Team 10. The almost non-existent theoretical production of the authors, as well as the strength that some purely architectural criteria acquire in the works critique, make a reading beyond aesthetic, technical or functional subjects difficult. The deliberate attempts of Herman Hertzberger to include concepts and references from other disciplines, which aim to open innovative ways of comprehending the architecture, have been disregarded for years, despite current efforts to retake its study. Tom Avermaete affirms that a definition of structuralism "as we know it in the fields of anthropology and literature [...] has always been, not about a particular style or a particular form, but about much more fundamental principles". (2)

The present use and spreading of the word 'structuralism' in the architectural sphere, force us to specify the implications that this term has exactly. Thus, this article is aligned with Francis Strauven's affirmation that does not deny the capability of the term, but criticizes its inappropriate use to generally refer to post-war Dutch architecture, advocating the utilization of other nomenclature, such as kasbahism or configurative architecture. As he points out in his contribution to 
estudio. Tom Avermaete asegura que "una lectura del estructuralismo como lo conocemos en las disciplinas de la antropología y la literatura tiene que ver, no con un estilo o una forma particular, sino con principios mucho más esenciales". (2)

El actual uso y divulgación del término estructuralismo, nos obliga a concretar exactamente las implicaciones que éste tiene. Así, este artículo se alinea con lo afirmado por Francis Strauven, que no niega la capacidad del término, sino que critica el inadecuado uso que se hace del mismo aplicado genéricamente a la arquitectura holandesa de posguerra, abogando por otros términos como casbaísmo o arquitectura configurativa. Como apunta en su aportación a la revista Volume, el concepto estructuralismo fue primeramente introducido en la escena arquitectónica por Herman Hertzberger en la presentación de su propuesta para el Ayuntamiento de Valkenswaard en 1966. El uso de este término se extendió a finales de los años sesenta de la mano de Arnaud Beerends, editor de $T A B K$, que, en opinión de Strauven, lo habría tomado prestado del propio Hertzberger. Finalmente, fue introducido en la escena arquitectónica internacional por Arnulf Lüchinger. (3)

Este artículo pretende mostrar un enfoque alternativo y eminentemente teórico de los supuestos que podrían haber dado soporte a la corriente del Estructuralismo Holandés. Para ello, nos centraremos en la obra de Herman Hertzberger, cuyas reflexiones teóricas sentaron las líneas clave que dotan al movimiento de contenido ideológico. El enfoque multidisciplinar de sus escritos nos permite iniciar una búsqueda de las influencias que más notablemente contribuyeron en su concepción arquitectónica. La realización de un análisis comparado en torno a una cuidadosa selección de conceptos estructurantes, pretende evaluar en qué medida existen convergencias entre el estructuralismo definido por Hertzberger y el estructuralismo desarrollado a lo largo del siglo xx en disciplinas como la antropología o la lingüística. El contenido principal se divide en cuatro apartados en los que, en primer lugar, se seleccionan y examinan varias teorías enunciadas por distintas figuras asociadas al estructuralismo, analizándose a continuación la traspo-

Volume magazine, Herman Hertzberger first introduced the concept structuralism in the architectural scene during the presentation of his proposal for Valkenswaard Town Hall in 1966. The employment of this term became widespread at the end of the sixties decade at the hands of Arnaud Beerends, editor of TABK journal who, in Strauven's opinion, would have borrowed it from Hertzberger. Eventually, the term was introduced into the international architectural scene by Arnulf Lüchinger. (3)

This article aims to show an alternative and mainly theoretical approach to the assumptions that could have given support to the architectural trend of Dutch structuralism. The analysis will be centred on the work of Herman Hertzberger, whose theoretical reflections laid the basis for the movement's provision with ideological content. The multidisciplinary approach to his writings allows us to start a searching of the influences that most notably contributed to his architectural conception. By conducting a comparative study around a careful selection of structuring concepts, it is intended to assess to what extent there are convergences between the architectural structuralism defined by Hertzberger, and the structuralism developed in other fields throughout the twentieth century, such as anthropology or linguistics. The main content is divided into four sections in which, after isolating and examining various theories enunciated by different figures related to structuralism, the transposition to architecture developed by Hertzberger is analysed, both in its theoretical and practical perspective. Thus, the proposed study intends to make Hertzberger's work comprehensible "in its own terms" rather than dissect it according to presumed categories, which will ensure, in the German philosopher Friedrich Schlegel's words, an "immanent critique". (4) 
sición a la arquitectura desarrollada por Hertzberger, tanto en su vertiente teórica como práctica. Así, el estudio propuesto huye de la disección del trabajo de Hertzberger de acuerdo con unas categorías prefijadas, buscando que se entienda "en sus propios términos", lo que garantizará, en palabras del filósofo alemán Friedrich Schlegel, "una crítica inmanente”. (4)

Ferdinand de Saussure: perspectiva dual. Tomamos como punto de partida a Ferdinand de Saussure, lingüista francés que, como indican Kronenfeld y Decker, sentó las bases de la lingüística estructural que subyace bajo el estructuralismo desarrollado en el siglo xx. (5) Cours de Liguistique Générale, la obra que sus discípulos editaron tras su muerte con el contenido más destacable de sus lecciones, recoge la esencia de sus descubrimientos. Su preocupación por la naturaleza contradictoria del lenguaje le lleva a plantear la hipótesis de que el lenguaje es un sistema que, dependiendo del referente temporal bajo el que se analice, se manifiesta en dos dimensiones divergentes, avanzando con las tesis de Baudouin de Courtenay sobre las invariantes y las variantes. (6) Bajo un análisis sincrónico, el lenguaje se presenta como un conjunto de elementos y leyes estables que en un momento determinado permiten la comunicación, lo que denomina la langue. Bajo un análisis diacrónico, el lenguaje se presenta como el conjunto cambiante de interpretaciones a lo largo del tiempo, lo que constituiría la parole. (7) Una de las claves de sus investigaciones es la naturaleza recíproca de ambas dimensiones, que se fundamentan la una en la otra. La langue se nutre de los cambios introducidos en la parole para evolucionar en el tiempo, mientras que la parole encuentra en la langue el conjunto de elementos, relaciones y reglas que permiten que la comunicación sea exitosa en un momento determinado.

Hertzberger incorpora esta doble dimensión a la arquitectura por medio de los términos 'trama' y 'urdimbre'. Un análisis sincrónico de la arquitectura se centra en la urdimbre, el conjunto de elementos y relaciones formales estables en un momento determinado, mientras que un análisis diacrónico giraría en torno a la trama, el conjunto de usos e interpretaciones que los usuarios hacen de la forma arquitectónica a lo largo del tiempo. Igual que con el lenguaje,
Fig. 3: Hertzberger, Herman: Residencia de ancianos De Drie Hoven, 1964-1974. Hertzberger, H. Lessons for Students in Architecture. Rotterdam: 010 Publishers, 1991.

Fig. 4: Hertzberger, Herman: Residencia de ancianos De Drie Hoven, 1964-1974. Bergeijk, H. van. Herman Hertzberger. Birkhäuser Verlag: Basilea/Boston/Berlín, 1997.
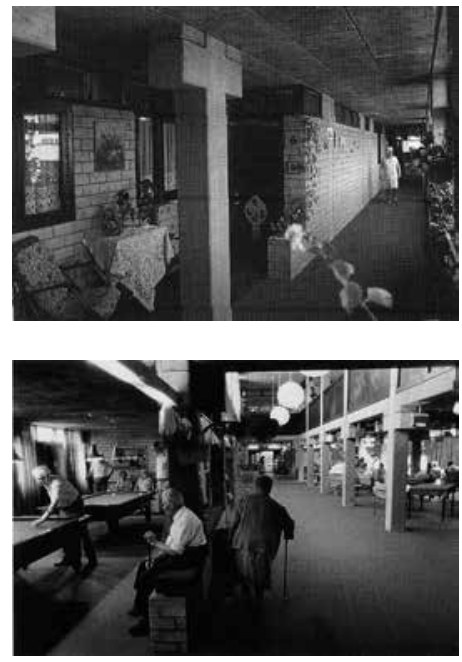

Ferdinand de Saussure: Dual Perspective. Ferdinand de Saussure is taken as a starting point. He was a French linguist who, as pointed out by Kronenfeld and Decker, laid the basis for the structural linguistics that lies under the structuralism developed in the twentieth century. (5) Cours de Liguistique Générale, the oeuvre edited by his disciples after his death with the most outstanding content of his lessons, gathers the essence of his discoveries. His concerns about the contradictory nature of language lead him to consider the hypothesis of language as a system that, depending on the temporal referent used in its analysis, manifests itself in two divergent dimensions, advancing the thesis of Baudouin de Courtenay on the invariants and the variants. (6) Under a synchronic analysis, language is presented as a group of elements and stable laws that, in a certain moment, allow communication, which he refers to as langue. Under a diachronic analysis, language is presented as the changing set of interpretations throughout time, which would constitute the parole. (7) One of the key aspects of his research is the reciprocate nature of both dimensions, which are grounded on each other. Langue is fed on the changes introduced in the parole to evolve in time; meanwhile, parole finds in the langue the set of elements, relationships and laws that allow communication to be successful in a certain moment.

Hertzberger incorporates this double dimension to architecture by means of the appellations warp and weft. A synchronic analysis of architecture is centred on the warp, the group of elements and formal relationships stable in a certain moment, whereas a diachronic analysis revolves around the weft, the set of uses and interpretations that users make of the architectural form everywhere in time. This architectural hypothesis can be linked to parallel advances in linguistics. Hertzberger affirms that "warp and weft make up an indivisible whole, [...] they give each other their purpose". (8) To the extent that the 
Hertzberger afirma que: "trama y urdimbre conforman un conjunto indivisible, [...] proporcionándose la una a la otra su propósito”. (8) En la medida en que la forma geométrica determina y facilita la interpretación de los usuarios, y los distintos usos a lo largo del tiempo redefinen sus relaciones internas, se demuestra que trama y urdimbre son recíprocas. La arquitectura por la que Hertzberger aboga se centra en el diseño de la urdimbre de tal forma que se incentiven distintas interpretaciones y usos por parte de los usuarios. Tomemos por ejemplo, la residencia para personas mayores De Drie Hoven en Amsterdam, diseñada entre 1959 y 1974. Entre otros mecanismos de diseño de la urdimbre, Hertzberger deforma el acceso a las habitaciones (Fig. 3) o los muros de separación entre los corredores y las zonas de juego, (Fig. 4) alentando a la apropiación estática del espacio por parte de los usuarios. La urdimbre, ese conjunto estable de elementos formales y relaciones espaciales, se manipula de tal forma que el usuario puede interpretar el espacio según le convenga, (Fig. 5) lo que puede devenir incluso en nuevos usos no contemplados.

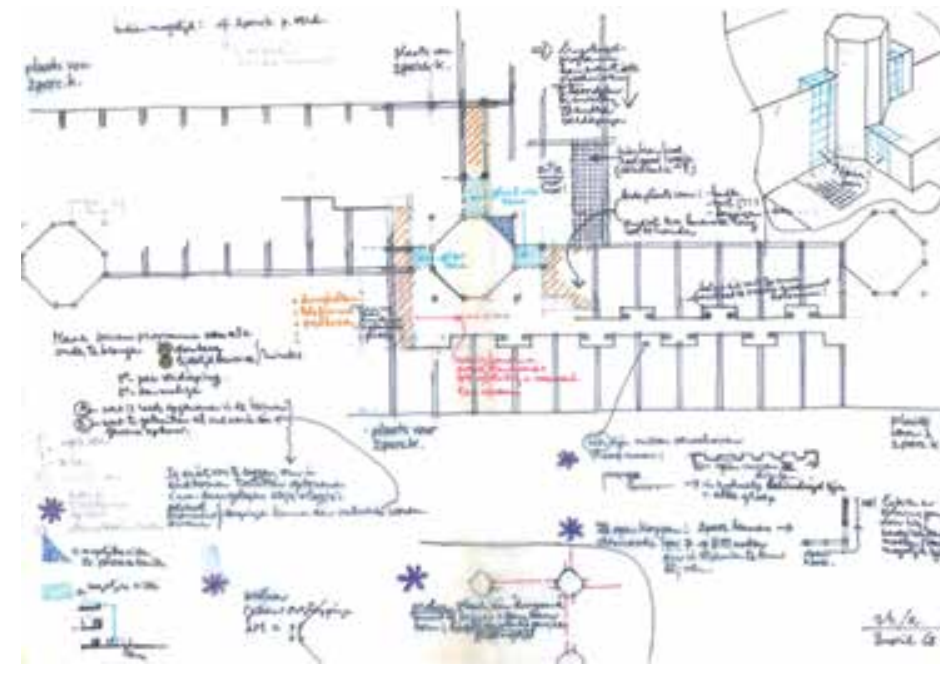

Fig. 5. Hertzberger, Herman: Residencia de ancianos De Drie Hoven, abril de 1968. Herman Hertzberger's Archive, Rijksarchief voor Nederlandse Architectuur en Stedenbouw, Het Nieuwe Instituut.

geometric form determines and eases the users' interpretation, and the different uses throughout time re-define its internal relationships, it is demonstrated that warp and weft are reciprocated. Hertzberger advocates an architecture that is centred on the design of the warp in such a way that diverse interpretations and usages by the users are fostered. We shall take as an example the complex for the elderly and disabled people De Drie Hoven, placed in Amsterdam and designed between 1959 and 1974. Amongst the design mechanisms of the warp, Hertzberger deforms the access to the rooms (Fig. 3) or the walls that separate the games rooms from the corridors, (Fig. 4) encouraging users to appropriate statically space. The warp, that stable group of formal elements and spatial relationships, is manipulated in such a way that the user can interpret space at his convenience, (Fig. 5) what can result even in new uses not considered until the date.

Roman Jakobson: Speaker and Hearer. The next outstanding figure is Roman Jakobson, who was the one that introduced Saussure's oeuvre and structural linguistics to Claude Lévi-Strauss. (9) His greater contribution to science gravitates towards the relationship between phonetics and structural linguistics. However, for this short reflection we are going to shift our focal point to an ancillary aspect of his investigations: the differentiation in structural linguistics of the roles of the speaker and the hearer. Jakobson distinguishes in every act of communication the figure of the encoder or speaker who, thanks to the code (langue), designs a message (parole), and the figure of the decoder or hearer who receives the message and codifies it afterwards. In his own words: "The speaker proceeds de verbo ad vocem, whereas the hearer proceeds in the opposite direction". (10) In his opinion, the most interesting thing about the act of communication is that the decoder or hearer is provided with a "subliminal statistical set" (11) in whose interpretation his own experience plays 
Roman Jakobson: emisor y receptor. La siguiente figura notable es Roman Jakobson, que fue quien introdujo la obra de Saussure y la lingüística estructural a Claude Lévi-Strauss. (9) Su mayor aportación a la ciencia se centra en la relación de la fonética con la lingüística estructural. Sin embargo, para esta breve reflexión vamos a desplazar nuestro punto focal a un aspecto secundario de sus investigaciones: la diferenciación de las figuras del 'emisor' y del 'receptor' en la lingüística estructural. Jakobson distingue en todo acto de comunicación la figura de un codificador o emisor que, a través del código (langue), diseña un mensaje (parole); y la del decodificador o receptor que recibe el mensaje y posteriormente lo codifica. En sus propias palabras: "El emisor procede de verbo ad vocem, mientras que el receptor procede en la dirección opuesta”. (10) Lo más interesante del acto de comunicación es que el receptor es dotado de un "conjunto estadístico subliminal", (11) en
Fig. 6. Hertzberger, Herman: Propuesta para área de negocios, Freising (Alemania), 1993. BERGEIJK, H. van. Herman Hertzberger. Birkhäuser Verlag: Basilea/Boston/Berlín, 1997.

Fig. 7. Hertzberger, Herman: Propuesta para área de negocios, Freising (Alemania), mayo de 1993. Herman Hertzberger's Archive, Rijksarchief voor Nederlandse Architectuur en Stedenbouw, Het Nieuwe Instituut.
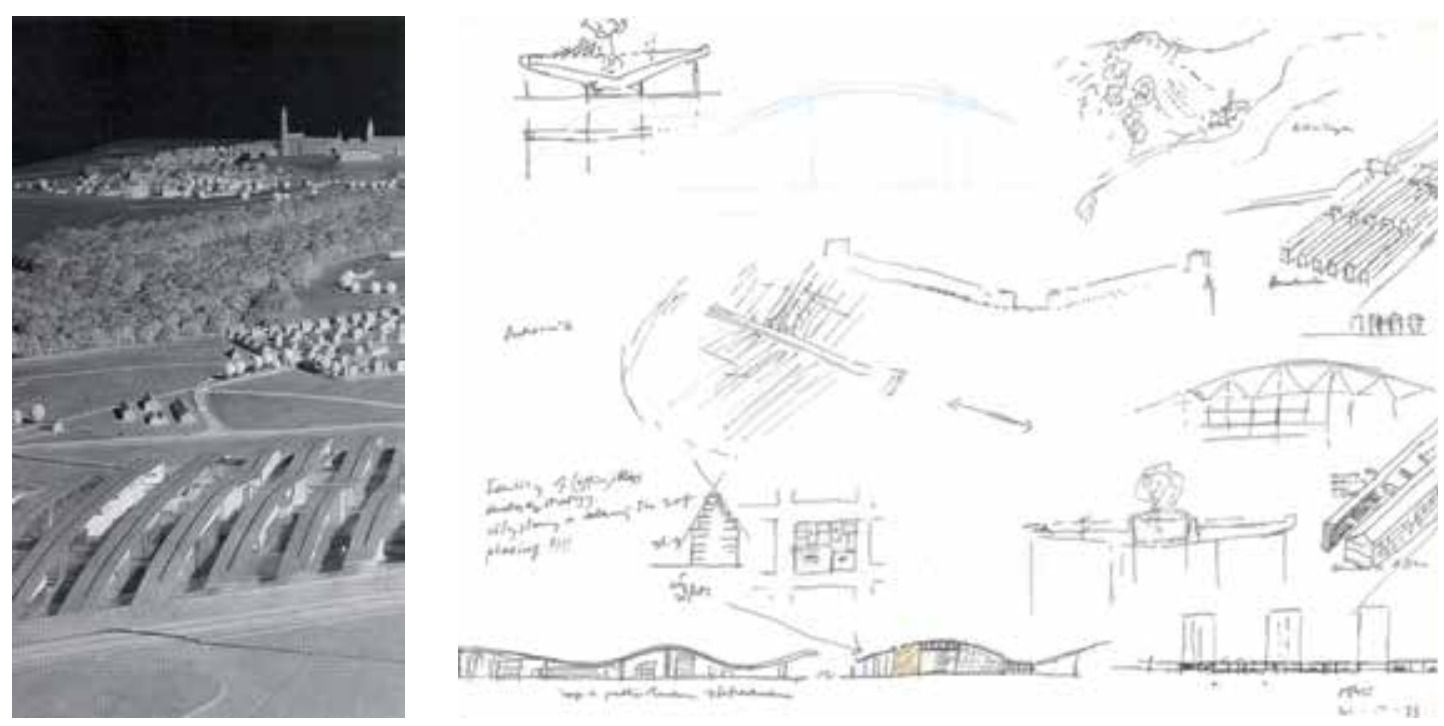

a fundamental role. Concerning the human mind's tendency towards abstraction, Jakobson compares grammar with geometry, maintaining that: "The abstractive power of human thought, underlying both geometrical relations and grammar, superimposes simple geometrical and grammatical figures upon the pictorial world of particular objects and upon the concrete lexical $[\ldots]$ of the verbal art". (12)

The application to architecture requires first a clear differentiation between the role of the encoder, the architect, and of the decoder, the user. The architect, who is able to recognise the geometrical form and the spatial relationships underlying the built environment, manipulates the warp during the design process, namely the group of elements and formal relationships. This provides the building with a certain degree of interpretability, that allows the development of diverse situations, what Jakobson refers to as 'statistical set'. In these circumstances, the user is able to relate to the surroundings in different ways depending firstly on his necessities, but also on his knowledge about the use of the form based on his own experience. We shall take as a reference the proposal, awarded first prize for the competition for a business area in Freising (Germany) in 1993. (Fig. 6) In an attempt to create a built landscape attractive to the user, Hertzberger abstracts a scheming gesture from the contour of Amsterdam's skyline, which is later employed in the manipulation of the project's warp with the clear intention to influence the users' interpretation and encourage a spatial use characteristic of the traditional urban milieu. (Fig. 7) In the Montessori school in Delft (The Netherlands), the same procedure is aimed at permitting greater freedom to experiment with forms and space rather than forcing a certain interpretation. In this educational building, Hertzberger pays special attention to the design of the children's play areas and the elements that separate the 
cuya interpretación juega un papel fundamental su propia experiencia. En relación a la tendencia a la abstracción de la mente humana, Jakobson compara la gramática con la geometría afirmando que: "El poder de abstracción del pensamiento humano, que subyace bajo las relaciones geométricas y gramaticales, superpone figuras geométricas y gramaticales simples sobre el mundo pictórico de los objetos particulares y sobre el léxico concreto [...] del arte verbal". (12)

La aplicación a la arquitectura pasa por diferenciar claramente entre el papel del emisor, el arquitecto, y el del receptor, el usuario. El arquitecto, que es capaz de reconocer la forma geométrica y las relaciones espaciales que subyacen bajo el entorno construido, manipula durante el proceso de diseño la urdimbre, es decir el conjunto de elementos y relaciones formales, dotando al edificio de un cierto rango de interpretabilidad que permite el desarrollo de distintas situaciones, lo que Jakobson denomina 'conjunto estadístico'. En esta circunstancia, el usuario es capaz de relacionarse con el entorno de diversas maneras dependiendo primeramente de sus necesidades, pero también del conocimiento de uso de la forma que posea en base a su propia experiencia. Tomemos como ejemplo la propuesta ganadora del primer premio en el concurso para el área de negocios en Freising (Alemania) en 1993. (Fig. 6) En un intento por crear un entorno construido atractivo para el usuario, Hertzberger abstrae del contorno de los edificios de Amsterdam un gesto que posteriormente emplea en la manipulación de la urdimbre del proyecto con la firme voluntad de influir en la interpretación de los usuarios y fomentar un uso característico del medio urbano tradicional. (Fig. 7) En la Escuela Montessori en Delft (Países Bajos), este mismo procedimiento se encamina, no a forzar una interpretación, sino a permitir una gran libertad de experimentación formal. En esta escuela, Hertzberger presta especial atención al diseño de las zonas de juego infantiles y los elementos de separación entre las aulas y las zonas comunes. (Fig. 8) La manipulación formal del suelo y el diseño del mobiliario permiten un gran número de configuraciones que son continuamente puestas a prueba por los niños. (Fig. 9)

classrooms from the common zones. (Fig. 8) The formal manipulation of the floor as well as the design of the furniture allow a wide range of arrangements, which are continuously put to the test by the children and the teachers. (Fig. 9)

Claude Lévi-Strauss: Structuralist Methodology. In this point, we turn our attention to the work of Claude LéviStrauss, the anthropologist whose discoveries were at the centre of the inquiries of other authors belonging to the socalled school of thought, structuralism. Trying to reconcile the two apparently opposite perspectives through which man faces the surrounding environment, the historical one and the structural one, he redefines the concept of 'structure. Thus, he advocates a methodological approach to social structures in which it is possible to discern "a system, ruled by an internal cohesiveness; and that this cohesiveness, inaccessible to observation [...] is revealed in the study of transformations, through which the similar properties in apparently different systems are discovered". (13) In Lévi-Strauss's opinion, the task of the ethnologist should be centred on extracting, by means of observation, those invariable features of outwardly distinct cultural facts that allow us to ascertain the common structures underlying all of them, providing a primary natural basis for study. Lévi-Strauss is, in this sense, close to Mauss' anthropology, which is directed towards the discovery of "what is common to men". Mauss asserts that if humankind is able to communicate through signs, it is only possible that they share those signs and that communication is possible, "because they have the same instincts". (14) In this process, the unconscious plays a fundamental role since it becomes the common denominator of humankind and it, subsequently, is set up as the starting point of every theory about the analysis of social structures. Ino Rossi affirms that the unconscious in Lévi-Strauss's writings "becomes a methodological device which enables one to give a unifying intelligibility to 


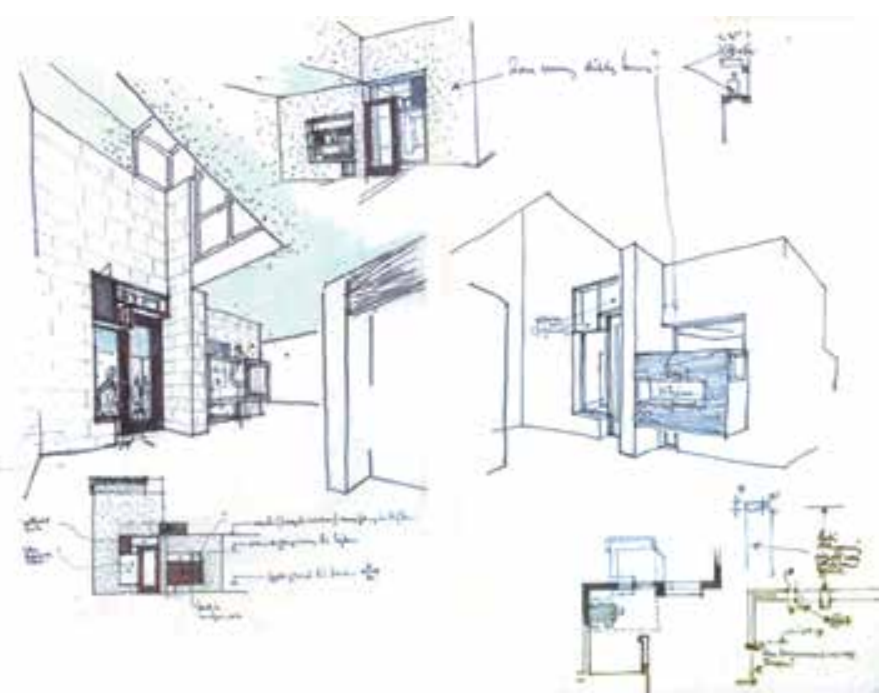

Claude Lévi-Strauss: método estructuralista. En este punto viramos nuestro estudio hacia el trabajo de Claude Lévi-Strauss, el antropólogo en torno a cuyos descubrimientos giró la denominada corriente estructuralista de las ciencias sociales. En un intento por reconciliar las dos visiones, histórica y estructural, mediante las cuales el hombre se enfrenta al mundo que le rodea, introduce el término de la 'estructura'. Así, apuesta por un método de aproximación a las estructuras sociales en el que sea posible discernirse "un sistema, regido por una cohesión interna; y que esa cohesión inaccesible a la observación [...] se revele en el estudio de las transformaciones, a través de las cuales se descubran propiedades similares en sistemas aparentemente dispares". (13) Según Lévi-Strauss la labor del etnólogo debe centrarse en extraer, a través de la observación, aquellos rasgos invariables de hechos culturales aparentemente diferentes que permitan descubrir las estructuras comunes que subyacen a todos ellos, dotándoles de una base natural y pri-

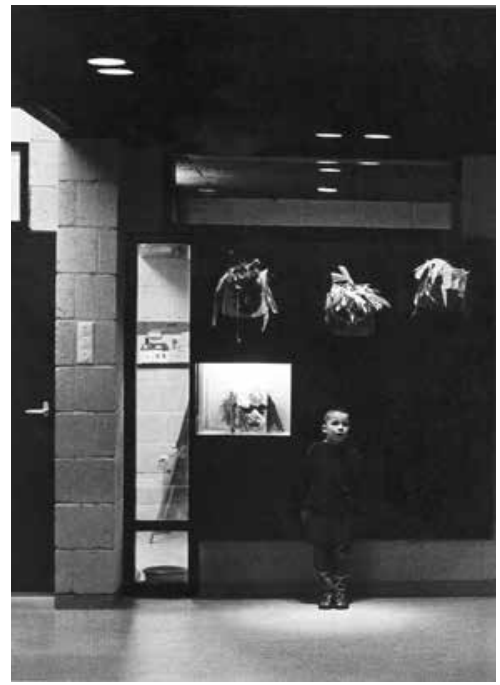

Fig. 8. Hertzberger, Herman: Escuela Montessori, Delft (Países Bajos), 1960-1966. Herman Hertzberger's Archive, Rijksarchief voor Nederlandse Architectuur en Stedenbouw, Het Nieuwe Instituut.

Fig. 9. Hertzberger, Herman: Escuela Montessori, Delft (Países Bajos), 1960-1966. Hertzberger, H. Articulations. Prestel: Munich/ Berlín/Londres/Nueva York, 2002.

apparently heterogeneous and incoherent social phenomena". (15) A continual attempt to reconcile different historical perspectives stems from the reading of Claude Lévi-Strauss' work, in which it is appreciated "a careful balancing of their respective claims to explanatory competence". (16) Hence, it is observed how his theories cleverly gather the advances of such disparate figures as Durkheim or Mauss, Freud, Marx, Saussure, Jakobson, or even Kant.

The translation of these principles into architecture revolves around the definition of structure as the synthesis of the warp and weft as mentioned above. Any structuralist approach to the architectural work, as a cultural feature with social implications, should necessarily face the study of the invariants, the group of architectural elements and their spatial relationships that we have defined as warp, and the succession of states throughout time that constitute the weft. Both dimensions are reciprocated to the extent that the series of interpretations and uses right through history reaffirm and provide coherence to the warp, whilst these interpretations and uses are only conceivable when a steady group of elements exists that supports them. In Hertzberger's judgment, the duty of the architect, as well as the ethnologist's one, should be centred on the invariants, rather than on the particularities, to respond to the needs of not only the individual, but also the assemblage of people. Thus, his or her different necessities are satisfied and "everyone's identity is optimal". (17) The role of the unconscious in the perception of architecture is essential to the extent that it imprints a series of presupposed categories on the built environment, which simultaneously allow and restrict interpretation based on a process of association. Interpretation, in Hertzberger's words, "is grounded in association" and generates "a degree of recognition in people, calling upon images rooted in earlier experience and in the unconscious". (18) The exemplification of these theories is 
maria. En este sentido se aproxima a la antropología de Mauss orientada al descubrimiento de "lo que es común a todos los hombres", que afirma que si la humanidad es capaz de comunicarse a través de símbolos, sólo es posible que compartan esos símbolos y que la comunicación sea posible "si poseen los mismos instintos". (14) En este proceso juega un papel fundamental el 'subconsciente', ya que se convierte en el común denominador a todas las personas y por tanto se erige como punto de partida de cualquier teoría de análisis de las estructuras sociales. Ino Rossi afirma que el subconsciente en la obra de Lévi-Strauss "se torna un mecanismo metodológico que permite al individuo dotar de una inteligibilidad unificadora a fenómenos sociales heterogéneos e incoherentes". (15) De la lectura de la obra de Lévi-Strauss se deriva un intento continuado por reconciliar distintas perspectivas históricas en conflicto por medio de "un balance cuidadoso de sus respectivos reclamos a la competencia explicativa". (16) Así, es posible observar como sus teorías aúnan inteligentemente avances de figuras tan dispares como Durkheim o Mauss, Freud, Marx, Saussure, Jakobson o incluso Kant.

La transposición a la arquitectura de estos principios se centra en la definición de la 'estructura' como la síntesis de la urdimbre y la trama mencionadas anteriormente. Cualquier aproximación estructuralista a la obra arquitectónica, como rasgo cultural con implicaciones sociales, necesariamente debe hacer frente al estudio de las invariantes, el conjunto de elementos arquitectónicos y sus relaciones espaciales que hemos definido como urdimbre, y a la sucesión de estados a lo largo del tiempo que constituyen la trama. Ambas dimensiones son recíprocas en la medida en que la sucesión de interpretaciones y usos a lo largo de la historia reafirman y aportan coherencia a la urdimbre, a la vez que sólo es posible dicha interpretación si existe un conjunto estable de elementos que la soporte. Según Hertzberger, la labor del arquitecto, igual que la del etnólogo, debe centrarse en las invariantes más que en las particularidades para dar respuesta no sólo al individuo, sino al conjunto de individuos. De esta forma se satisfarán sus distintas necesidades y "la identidad de cualquier usuario será óptima”. (17) El papel del subconsciente en la percepción de la arquitectura es clave, en la medida

observed in Centraal Beheer office building in Apeldoorn (The Netherlands), where the warp designed by Hertzberger is founded on a grid, (Fig. 10) along which two different spatial realities are accommodated. On the one hand, a network of traffic areas with a vertical proportion and a glass ceiling that allows sunlight to enter inside the complex, and, on the other hand, a matrix of towers whose inner space possesses a sharp horizontal proportion. Hertzberger, looking for harmonizing work activity with the social function, (19) appeals to the spatial dichotomy characteristic of the city, aiming to incite a more collective use in the traffic networks and a more individual use in the inner space of the towers. When perceiving the vertical proportion of the areas of circulation, (Fig. 11) the user associates the space with the urban environment, interpreting it as such and relating to the rest of users and the surrounding environment as he would do it in the public sphere.

Noam Chomsky: Competence and Performance. The search of correspondences between the work of Hertzberger and the most celebrated structuralist authors concludes with the figure of Noam Chomsky, the linguist who developed new theories that gave a renewed boost to structural linguistics in the second half of the twentieth century. Among his inquiries, the distinction between 'competence' and 'performance' is one of the most noteworthy themes, being the competence of language the object of the synchronic analysis and the performance the object of the diachronic approach. The fundamental property of language is, as stated by Everaert and others, that it "provides a means for expressing indefinitely many thoughts and for reacting appropriately in an indefinite range of new situations". (20) Taking this for granted, the key question is how to demonstrate the above hypothesis - as to whether it exists as an unconscious structure that 
en que imprime una serie de categorías prefijadas sobre el entorno construido que, a la vez, permiten y limitan la interpretación en base a un proceso de asociación. La interpretación, en palabras de Hertzberger, "se basa en la asociación [...] que genera un grado de reconocimiento en la gente, evocando imágenes enraizadas en nuestra experiencia anterior y en el subconsciente". (18) La ejemplificación de lo anterior se observa en el edificio de oficinas Centraal Beheer en Apeldoorn (Países Bajos), donde Hertzberger diseña la urdimbre basándose en una retícula, (Fig. 10) a lo largo de la que se desarrollan dos realidades espaciales distintas: por un lado una red de espacios de circulación con una proporción vertical y una cubierta acristalada que permite la entrada de luz solar, y por otro, una matriz de torres en las que el espacio interior posee marcada proporción horizontal. Hertzberger, en una búsqueda por compatibilizar la actividad laboral con la función social, (19) recurre a la dicotomía del espacio de la ciudad, buscando incentivar un uso más social en las redes de circulación y un uso más individual en el interior de las torres. El usuario al percibir la proporción vertical de los espacios de circulación, (Fig. 11) asocia el espacio con un entorno urbano, interpretándolo como tal y relacionándose como lo haría en una vía pública.

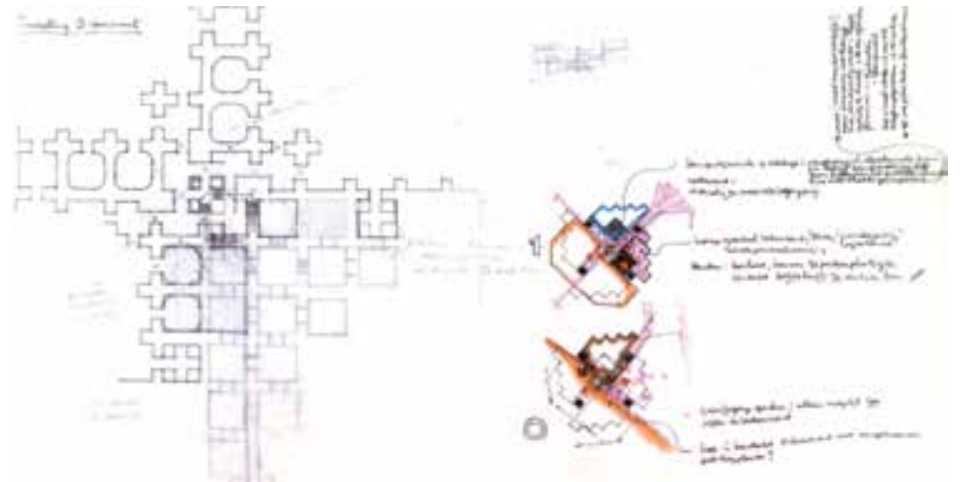

Fig. 10. Hertzberger, Herman: Edificio de oficinas Centraal Beheer, Apeldoorn (Países Bajos), noviembre de 1968. Herman Hertzberger's Archive, Rijksarchief voor Nederlandse Architectuur en Stedenbouw, Het Nieuwe Instituut.

restricts, while permits, interpretation - Chomsky resolves that the group of elements and internal relationships of language possesses "certain possibilities of parametric variation", which constitutes the "initial state" in a specific moment, being susceptible of suffering an evolution "under the triggering and shaping effect of experience" that would result in a new state "more or less steady". (21) The creative aspect of language use that belongs to the sphere of language performance, plays an essential part in this evolution, which is only possible, in Chomsky's words, thanks to the "rules and principles of grammar" (22) that comprise language competence.

The translation into architecture leads us to the concept of the polyvalent architectural form, the spatial configuration that, according to Hertzberger, "without changing itself can be used for every purpose and which, with minimal flexibility, allows an optimal solution". (23) To the extent that it is allowed by the group of elements and internal relationships, the work of architecture possesses a distinctive competence in a specific moment, i.e. a set of uses and interpretations of space already assimilated in the collective consciousness through which it is aimed to give response to the expected necessities of users. This competence changes throughout time by means of the association of new unexpected uses and interpretations with the geometrical form, which are developed under the user's new demands. What gives rise to their normalization and subsequent ascription to the competence of the architectural form, is the continual application everywhere in time. The competence of the architectural form changes, therefore, from the initial state to a transformed state, as happened to language in Chomsky's opinion. In the experimental housing in Delft (The Netherlands) designed in 1967 and built in 1970, (Fig. 12) since the project decision making it is considered that the group of elements and formal relationships that comprise the 
Noam Chomsky: competencia y rendimiento. La búsqueda de correspondencias entre el trabajo de Hertzberger y los más reconocidos autores estructuralistas concluye en la figura de Noam Chomsky, lingüista que, en la segunda mitad del siglo $\mathrm{xx}$, desarrolló nuevas teorías en relación a la lingüística estructural. De su obra nos interesa especialmente la distinción entre 'competencia' y 'rendimiento', siendo la competencia del lenguaje el objeto del análisis sincrónico y el rendimiento o actuación el objeto del enfoque diacrónico. La propiedad fundamental del lenguaje, según Everaert y otros, es que "proporciona un medio para expresar indefinidamente distintos pensamientos y para reaccionar apropiadamente en un rango indefinido de nuevas situaciones". (20) La cuestión, en este supuesto, es cómo se demuestra lo anterior si existe una estructura subconsciente que limita, a la vez que permite, la interpretación. Chomsky resuelve que el conjunto de elementos y relaciones internas del lenguaje poseen una "capacidad limitada de variación paramétrica", lo que en un determinado momento constituye el "estado inicial", siendo susceptible de sufrir una evolución "bajo el efecto desencadenante y conformador de la experiencia”, que daría lugar a nuevo estado "más o menos estable". (21) En esta evolución juega un papel esencial el aspecto creativo del uso del lenguaje, ubicado dentro del rendimiento o actuación, que según Chomsky sólo es posible gracias a las "reglas y principios de la gramática" que conforman la competencia del lenguaje. (22)

La trasposición a la arquitectura nos conduce al concepto de la forma arquitectónica polivalente, aquella forma que, según Hertzberger, "sin cambiar en sí misma puede ser usada para cada fin y que, con una mínima flexibilidad, permite una solución óptima”. (23) La obra de arquitectura, en la medida en que sus elementos y relaciones internas lo permiten, posee una determinada competencia en un momento determinado, un conjunto de usos e interpretaciones de los espacios ya asimilados en la conciencia colectiva con los que se quiere dar respuesta a las necesidades esperables de los usuarios. Esta competencia varía con el paso del tiempo, por medio de la asociación a la forma geométrica de nuevos usos e interpretaciones no previstos que se desarrollan bajo nuevas demandas de los usuarios. Es

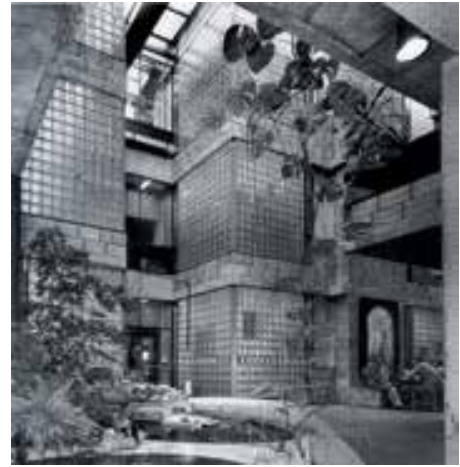

Fig. 11. Hertzberger, Herman: Edificio de oficinas Centraal Beheer, Apeldoorn (Países Bajos), 1968-1972. Bergeijk, H. van. Herman Hertzberger. Birkhäuser Verlag: Basilea/ Boston/Berlín, 1997.

space, the so-called warp, can accommodate different interpretations and so respond to the changing needs all over time. The architect's answer through the architectural project is a polyvalent construction that can be used in diverse ways depending on the situation. (Fig. 13) This does not imply that no more uses than expected are possible. The new necessities, new family configurations, etc., will determine the forthcoming competence of the architectural form.

Conclusions. As it is observed, it is possible to generate a cross-sectional discourse on architecture and social sciences by using the main advances developed in linguistics and anthropology during the last century as guidelines. The convergences highlighted in the four sections, demonstrate the existence of a clear correspondence between the architecture promoted by Herman Hertzberger and the inquiries of Saussure, Jakobson, Lévi-Strauss and Chomsky. The choice of the word Structuralism referring to the work of Herman Hertzberger is considered, therefore, appropriate and opportune.

The direct translation of the structuralist principles to our discipline is materialized in form of a gnosiology of architecture, whose application is valid for every building, independently of the style under which it is designed. This approach, where the temporal referent becomes determinant, necessarily pays attention to the steady group of formal elements and spatial relationships, as well as to the set of uses and interpretations that occur throughout time. Furthermore, the superimposition of the structuralist principles in its practical side, presents an architecture in pursuance of certain criteria that reflect a consideration of the dual nature underlying all structure from the initial stages of the design. Among these criteria, the contemplation of the time factor as key in the configuration of space, is remarkable, in the extent that the architectural differentiation of the synchronic and diachronic dimensions is perceivable through the prism of time. 
la aplicación continuada en el tiempo lo que deriva en su normalización y adscripción a la forma arquitectónica. La competencia de la forma varía así, desde un estado inicial a un estado transformado, como ocurre con el lenguaje según Chomsky. En las viviendas experimentales Diagoon en Delft (Países Bajos) diseñadas en 1967 y construidas en 1970, (Fig. 12) desde la idea de proyecto se tiene en cuenta que el conjunto de elementos y relaciones formales que conforman el espacio, la urdimbre, pueden admitir distintas interpretaciones y dar respuesta a necesidades variables a lo largo del tiempo. La respuesta del arquitecto por medio del proyecto es un edificio polivalente que puede utilizarse de distintas formas dependiendo de la situación. (Fig. 13) Esto no significa que no sean posibles más usos de los previstos. Serán las nuevas necesidades, las nuevas configuraciones familiares, etc., las que determinen su futura competencia.

Conclusiones. Como se observa, es posible generar un discurso transversal entre arquitectura y ciencias sociales tomando como ejes los principales avances desarrollados en lingüística y antropología del pasado siglo. Las convergencias destacadas en los cuatro apartados demuestran la existencia de una correspondencia clara entre la arquitectura promovida por Herman Hertzberger y la obra de Saussure, Jakobson, Lévi-Strauss y Chomsky. La elección del término estructuralismo en referencia al trabajo de Herman Hertzberger se considera, por tanto, adecuada y oportuna. La trasposición directa de los principios estructuralistas a nuestra disciplina se materializa en forma de una gnoseología de la arquitectura, cuya aplicación es válida para cualquier edificio, independientemente del estilo bajo el que se proyecte. Esta aproximación, en la que el referente temporal se erige determinante, necesariamente atiende, por un lado, al conjunto de elementos formales y relaciones espaciales estables, y por otro, al conjunto de interpretaciones y usos que a lo largo del tiempo acontecen en su seno. Además, la superposición de los principios estructuralistas en su vertiente más práctica, presenta una arquitectura en la que el seguimiento de ciertos criterios refleja una consideración, desde la génesis del proyecto, de la naturaleza dual que subyace a toda estructura.

Concerning this condition, the work of architecture is designed based on some invariants, which aim to satisfy the necessities common to the assemblage of individuals, and on some variants, which safeguard their diversity and particularities. Another pursued criterion, is the design of the architectural form in such a way that the capacity of choice of the assemblage of users is increased, depending on their needs and previous knowledge - that guarantees the maximum fulfilment of human beings, both in its individual significance and in its social one - Finally, the adaptability of the built artefact is intimately linked to a certain kind of sustainability by means of which, the building possesses a greater useful life, to the extent that it can admit change without losing its identity.

Given the universal scope of a structuralist epistemology of architecture, it is precisely the superimposition of the structuralist principles in its practical dimension that can lead to define the particularities of an architectural trend, since it is limited by certain design criteria. A reading of the work of architecture through the prism of the structuralist precepts, allows us to isolate the two complementary dimensions that in turn are needed to analyse the strategies of design mentioned above. The contribution of structuralism to architecture is, precisely, to make intelligible some qualitative aspects that could not be studied in their original context otherwise. Regarding the controversy caused by the widespread use of the term structuralism to generally refer to the Netherlander architecture of the second half of the last century, it shall be the object of forthcoming research to assess whether the examples traditionally connected to Dutch Structuralism converge or diverge with the essential themes extracted. An overview of the influence that these themes could have on the decisionmaking of the diverse works of architecture, shall occasionally demonstrate the greater or lesser aptitude of the term. 
Entre estos criterios destaca, en primer lugar, la consideración del factor tiempo como clave en la configuración del espacio, en tanto que a través del prisma temporal es posible la diferenciación de las dimensiones sincrónica y diacrónica de la arquitectura. En relación con este criterio, el edificio de arquitectura se diseña con base en unas invariantes, que buscan satisfacer las necesidades comunes al conjunto de individuos, y unas variantes, que salvaguardan su diversidad y particularidades. Otro criterio perseguido es el diseño de la forma arquitectónica de tal manera que incremente la capacidad de elección del conjunto de los individuos dependiendo de sus necesidades y su conocimiento previo, lo que garantiza la plena realización del ser humano, tanto en su vertiente individual como social. En último lugar, la adaptabilidad del artefacto construido está íntimamente vinculada con un cierto tipo de sostenibilidad por medio de la cual el edificio poseería una mayor vida útil en la medida en que es capaz de admitir el cambio sin perder la identidad.

Dado el alcance universal de una epistemología de la arquitectura estructuralista, es precisamente la superposición de los principios estructuralistas en su dimensión práctica la que, por ajustarse a ciertos criterios de diseño, puede llegar a definir las particularidades de una corriente arquitectónica. Una revisión de la obra de arquitectura a través del prisma de los preceptos estructuralistas, nos permite aislar las dos dimensiones complementarias que, a su vez, son necesarias para analizar las estrategias de diseño mencionadas anteriormente. La aportación del estructuralismo a la arquitectura es, precisamente, hacer inteligibles aspectos cualitativos que, de otra forma, no podrían ser estudiados en su contexto original. En relación a la controversia que suscita el uso del término estructuralismo para referirse, genéricamente, a la arquitectura neerlandesa de la segunda mitad de siglo, será objeto de futuras investigaciones evaluar si los ejemplos que tradicionalmente han sido asociados al movimiento convergen o divergen con los temas clave extraídos. Un estudio panorámico sobre la influencia que estos temas pudieron tener en la toma de decisiones de las distintas obras de arquitectura eventualmente demostrará la mayor o menor aptitud del término.
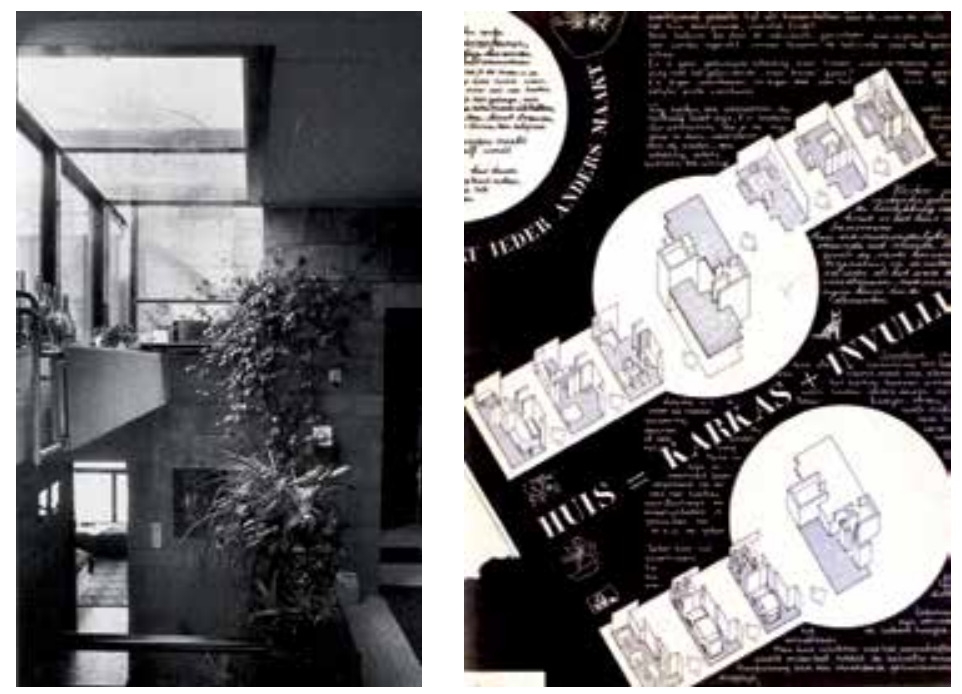

Fig. 12. Hertzberger, Herman: Viviendas experimentales Diagoon, Delft (Países Bajos), 1969-1970. Bergeijk, H. van. Herman Hertzberger. Birkhäuser Verlag: Basilea/Boston/ Berlín, 1997.

Fig. 13. Hertzberger, Herman: Viviendas experimentales Diagoon, Delft (Países Bajos), 1969-1970. Herman Hertzberger's Archive, Rijksarchief voor Nederlandse Architectuur en Stedenbouw, Het Nieuwe Instituut. 


\section{NOTAS}

1. Declaraciones realizadas durante la entrevista mantenida en su estudio HH Architectuurstudio en Amsterdam el 16 de noviembre de 2016. 2. HEUVEL, D. van den (ed.) y FRAUSTO, S. (ed.) 'Open Structures: An Introductory Dossier on Dutch Structuralism'. Volume vol. 35, núm. 1, 2013. p. 68.

3. Como apunta Strauven, fue el editor Arnulf Lüchinger quien introdujo el término estructuralismo en la escena arquitectónica internacional en 1971 a través de la revista Bauen und Wohnen. HEUVEL, D. van den y otros. 'Structuralism: An Installation in Four Acts'. Volume vol. 42, 2014. p. 107. 4. En el número 81 de la revista $O A S E$, centrado en la crítica arquitectónica como medio esclarecedor de la "riqueza semántica de la obra de arquitectura", Peter Bürger aboga por un juicio positivo de la obra de arte que tenga en cuenta los criterios intrínsecos claves en su creación y que aporte cualidades añadidas no asociadas hasta la fecha. Bürger hace referencia al modelo de crítica inmanente introducido por Schlegel, que enfatiza aquellos rasgos específicos de la obra de arte de acuerdo a los que desea ser leída y que constituyen la base de su estudio. Una evaluación de la obra de Hertzberger bajo los preceptos estructuralistas intrínsecos en la toma de decisiones del proyecto, es un ejemplo de crítica inmanente que desvela aspectos cualitativos inaccesibles de otra forma. AVERMAETE, T. y otros. 'Editorial'. OASE núm. 81, junio 2010. pp. 1-10. BÜRGER, P. 'Begrip en Grenzen van de Kritiek/ Definitions and Limitations of Criticism. OASE núm. 81, junio 2010. p. 30.

5. "Lévi-Strauss ha modelado su antropología estructural sobre la lingüística estructural moderna. La figura clave en la definición de la naturaleza y el empeño de la lingüística estructural, [...] fue de Saussure." KRONENFELD, D. y DECKER, H.W. 'Structuralism'. Annual Review of Anthropology núm. 8, 1979. p. 505.

6. "En 1871, Badouin de Courtenay hizo la declación lingüistica de que 'lo que necesitamos saber es la relación entre los invariantes y los variantes.' El invariante es la idea básica.” En JAKOBSON, R. 'A Few Remarks on Structuralism' $M L N$, vol. 91, núm. 6, diciembre 1976. p. 1538.

7. SAUSSURE, F. de. Cours de Linguistique Générale. París: Payot, 1962. 8. HERTZBERGER, H. Lessons for Students in Architecture. Rotterdam: 010 Publishers, 1991, p. 108.

\section{REFERENCIAS}

AVERMAETE, T., GRAFE, C., HAVIK, K., LAGAE, J., PATTEEUW, V., TEERDS, H. y VANDEPUTTE, T. 'Editorial. OASE núm. 81, junio 2010, pp. 1-10. BADCOCK, C.R. y LÉVI-STRAUSS, C. 'The Ecumenical Anthropologist: Solutions to Some Persistent Problems in Theoretical Sociology Found in the Works of Claude Lévi-Strauss. The British Journal of Sociology vol. 26, núm. 2, junio 1975, pp. 156-168.

BÜRGER, P. 'Begrip en Grenzen van de Kritiek/ Definitions and Limitations of Criticism'. OASE núm. 81, junio 2010, pp. 13-32.

CHOMSKY, N. 'Knowledge of Language: Its Elements and Origins'. Philosophical Transactions of the Royal Society of London. Series B, Psychological Sciences vol. 295, núm. 1077, octubre 1981, pp. 223-234.

CHOMSKY, N. 'A Note on the Creative Aspect of Language Use'. The Philosophical Review vol. 91, núm. 3, julio 1982, pp. 423-434.

EVERAERT, M.B.H., HUYBREGTS, M.A.C., CHOMSKY, N., BERWICK, R.C. y BOLHUIS, J.J. 'Structures, Not Strings: Linguistics as Part of the Cognitive Sciences. Trends in Cognitive Sciences. vol. 19, núm. 12, diciembre 2015, pp. 729-743. HERTZBERGER, H. 'Flexibiliteit en Polivalentie/ Flexibility and Polivalency'. Forum núm. 3, 1962, pp. 115-122.

HERTZBERGER, H. 'Identiteit'. Forum núm. 7, 1967, pp. 17-18. HERTZBERGER, H. Lessons for Students in Architecture. Rotterdam: 010 Publishers, 1991.
9. "El trabajo inicial de Saussure en lingüística estructural fue desarrollado, ampliado e integrado significativamente junto con el de la Escuela de Kazan por Troubetzkoy, Jakobson, y otros autores de la Escuela de Praga. Jakobson, durante la década de los cuarenta en Nueva York, introdujo a Lévi-Strauss a la lingüística estructural en general y a la obra de Saussure en particular". En KRONENFELD, D. y DECKER, H.W. 'Structuralism'. Annual Review of Anthropology núm. 8, 1979, p. 509.

10. JAKOBSON, R. 'Sign and System of Language: A Reassessment of Saussure's Doctrine'. Poetics Today. vol. 2, núm. 1a, 1980, p. 37.

11. Ibid, p. 37.

12. JAKOBSON, R. 'Poetry of Grammar and Grammar of Poetry'. Lingua núm. 21, 1968. p. 606.

13. LÉVI-STRAUSS, C. 'The Scope of Anthropology'. Current Anthropology vol. 7, núm. 2, abril 1966, p. 118.

14. Ibid, p. 120.

15. ROSSI, I. 'The Unconscious in the Anthropology of Lévi-Strauss'. American Anthropologist, New Series vol. 75, núm. 1, febrero 1973, p. 42. 16. BADCOCK, C.R. y LÉVI-STRAUSS, C. 'The Ecumenical Anthropologist: Solutions to Some Persistent Problems in Theoretical Sociology Found in the Works of Claude Lévi-Strauss'. The British Journal of Sociology vol. 26, núm. 2, junio 1975, p. 167.

17. HERTZBERGER, H. 'Identiteit'. Forum núm. 7, 1967, p. 17.

18. HERTZBERGER, H. Herman Hertzberger: Architecture and Structuralism. Rotterdam: NAi 010, 2015, p. 117.

19. MERINO, R., GRIJALBA, J. y GRIJALBA, A. 'Paisajes urbanos. El edificio como una ciudad. Centraal Beheer'. $Z A R C H$ núm. 7, 2016, pp. 154. 20. EVERAERT, M.B.H. y otros. 'Structures, Not Strings: Linguistics as Part of the Cognitive Sciences. Trends in Cognitive Sciences vol. 19, núm. 12, diciembre 2015, p. 732.

21. CHOMSKY, N. 'Knowledge of Language: Its Elements and Origins'. Philosophical Transactions of the Royal Society of London. Series B, Psychological Sciences vol. 295, núm. 1077, octubre 1981, p. 224.

22. CHOMSKY, N. 'A Note on the Creative Aspect of Language Use'. The Philosophical Review vol. 91, núm. 3, julio 1982, p. 425.

23. HERTZBERGER, H. 'Flexibiliteit en Polivalentie/ Flexibility and Polivalency'. Forum núm. 3, 1962, p. 117.

HERTZBERGER, H. Herman Hertzberger: Architecture and Structuralism. Rotterdam: NAi 010, 2015.

HEUVEL, D. van den (ed.) y FRAUSTO, S. (ed.) 'Open Structures: an Introduc tory Dossier on Dutch Structuralism'. Volume vol. 35, núm. 1, 2013, pp. 65-96. HEUVEL, D. van den, BLOM, P., STRAUVEN, F., OOSTERMAN, A., VOLLAARD, P., HARDY, J., y BEUMER, G. 'Structuralism: An Installation in Four Acts'. Volume vol. 42, 2014, pp. 81-112.

JAKOBSON, R. 'Poetry of Grammar and Grammar of Poetry'. Lingua núm. 21, 1968, pp. 597-609.

JAKOBSON, R. 'A Few Remarks on Structuralism'. MLN vol. 91, núm. 6, diciembre 1976, pp. 1534-1539.

JAKOBSON, R. 'Sign and System of Language: A Reassessment of Saussure's Doctrine'. Poetics Today vol. 2, núm. 1a, 1980, pp. 33-38. KRONENFELD, D. y DECKER, H.W. 'Structuralism'. Annual Review of Anthropology núm. 8, 1979, pp. 503-541.

LÉVI-STRAUSS, C. 'The Scope of Anthropology' Current Anthropology vol. 7, núm. 2, abril 1966, pp. 112-123. MERINO, R., GRIJALBA, J. y GRIJALBA, A. 'Paisajes urbanos. El edificio como una ciudad. Centraal Beheer'. ZARCH núm. 7, 2016, pp. 144-157. ROSSI, I. 'The Unconscious in the Anthropology of Lévi-Strauss'. American Anthropologist, New Series vol. 75, núm. 1, febrero 1973, pp. 20-46. SAUSSURE, F. de. Cours de Linguistique Générale. París: Payot, 1962. 


\section{NOTES}

1. Statement issued by Herman Hertzberger during the interview at the office HH Architectuurstudio located in Amsterdam on the 16th of November 2016.

2. HEUVEL, D. van den (ed.) y FRAUSTO, S. (ed.) 'Open Structures: An Introductory Dossier on Dutch Structuralism'. Volume vol. 35, núm. 1, 2013. pp. 68.

3. As pointed out by Strauven, the term structuralism was introduced to the international architectural scene by the editor Arnulf Lüchinger in 1971, through Bauen und Wohnen. HEUVEL, D. van den and others. 'Structuralism: An Installation in Four Acts'. Volume vol. 42, 2014. pp. 107. 4. In the number 81 of OASE journal, centred on the architectural critique as an enlightening means of "the semantic richness of the architectural object", Peter Bürger advocates a positive judgement of artwork that takes account of the intrinsic criteria key in its creation and that provides added qualities not considered until that date. Bürger refers to the immanent critique model introduced by Schlegel, which emphasizes those specific features of artwork according to which "it wishes to be read" and that constitute "the basis of the reading". An assessment of Herman Hertzberger's work, under the intrinsic structuralist principles considered during the project decision making, is an example of immanent critic that reveals otherwise inaccessible qualitative aspects. AVERMAETE, T. and others. 'Editorial'. OASE núm. 81, junio 2010. pp. 1-10. BÜRGER, P. 'Begrip en Grenzen van de Kritiek/ Definitions and Limitations of Criticism'. OASE num. 81, june 2010. pp. 30.

5. "Lévi-Strauss ha modelado su antropología estructural sobre la lingüística estructural moderna. has modelled his structural anthropology on modern structural linguistics. The key figure in the definition of the nature and task of structural linguistics, [...] was de Saussure." KRONENFELD, D. y DECKER, H.W. 'Structuralism'. Annual Review of Anthropology num. 8, 1979. pp. 505.

6. "In 1871 Baudouin de Courtenay made the linguistic declaration 'what we need to know is the relation between the invariant and variant'. The invariant is the basic idea". In JAKOBSON, R. 'A Few Remarks on Structuralism. $M L N$, vol. 91, num. 6, december 1976. pp. 1538.

7. SAUSSURE, F. de. Cours de Linguistique Générale. París: Payot, 1962. 8. HERTZBERGER, H. Lessons for Students in Architecture. Rotterdam: 010
Publishers, 1991, pp. 108.

9. "Saussure's initial work in structural linguistics was significantly developed, amplified, and integrated with that of the Kazan school by Troubetzkoy, Jakobson, and others in the Prague school. Jakobson, during the 1940s in New York, introduced Lévi-Strauss to structural linguistics in general and to Saussure's work in particular". In KRONENFELD, D. y DECKER, H.W. 'Structuralism'. Annual Review of Anthropology num. 8, 1979, pp. 509.

10. JAKOBSON, R. 'Sign and System of Language: A Reassessment of Saussure's Doctrine'. Poetics Today. vol. 2, num. 1a, 1980, pp. 37.

11. Ibid, pp. 37.

12. JAKOBSON, R. 'Poetry of Grammar and Grammar of Poetry'. Lingua num. 21, 1968. pp. 606.

13. LÉVI-STRAUSS, C. 'The Scope of Anthropology'. Current Anthropology vol. 7, num. 2, April 1966, pp. 118.

14. Ibid, pp. 120.

15. ROSSI, I. 'The Unconscious in the Anthropology of Lévi-Strauss'. American Anthropologist, New Series vol. 75, num. 1, February 1973, pp. 42.

16. BADCOCK, C.R. and LÉVI-STRAUSS, C. 'The Ecumenical Anthropologist: Solutions to Some Persistent Problems in Theoretical Sociology Found in the Works of Claude Lévi-Strauss'. The British Journal of Sociology vol.

26, núm. 2, June 1975, pp. 167.

17. HERTZBERGER, H. 'Identiteit'. Forum num. 7, 1967, pp. 17.

18. HERTZBERGER, H. Herman Hertzberger: Architecture and Structuralism. Rotterdam: NAi 010, 2015, pp. 117.

19. MERINO, R., GRIJALBA, J. and GRIJALBA, A. 'Paisajes urbanos. El edificio como una ciudad. Centraal Beheer'. ZARCH num. 7, 2016, pp. 154. 20. EVERAERT, M.B.H. and others. 'Structures, Not Strings: Linguistics as Part of the Cognitive Sciences. Trends in Cognitive Sciences vol. 19, núm. 12, December 2015, pp. 732.

21. CHOMSKY, N. 'Knowledge of Language: Its Elements and Origins'. Philosophical Transactions of the Royal Society of London. Series B, Psychological Sciences vol. 295, num. 1077, octubre 1981, pp. 224.

22. CHOMSKY, N. 'A Note on the Creative Aspect of Language Use'. The Philosophical Review vol. 91, núm. 3, julio 1982, p. 425.

. HERTZBERGER, H. 'Flexibiliteit en Polivalentie/ Flexibility and Polivalency'. Forum num. 3, 1962, pp. 117.

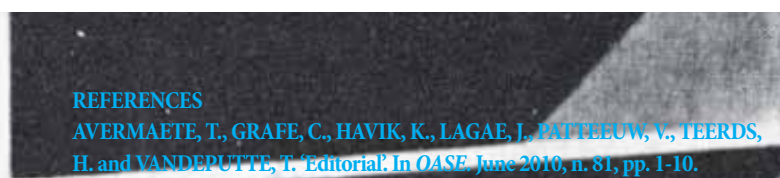

H. and VANDEPUHH, T. Editorial'. In OASE, June-2010,1. 81, p. 1-10.

BADCOCK, C.R. and LEVI-STRAUSS, C. 'The Ecumenical Anthropologist: Solutions to Some Persistent Problems in Theoretical Sociology Found in the Works of Claude Lévi-Strauss.' In: The British Journal of Sociology 1975 , vol. 26 , n. 2 , pp. 156-168. BÜRGER, P. 'Begrip en Grenzen van de Kritiek/ Definitions and of Criticism? In: OASE. June 2010, no. 81, pp. 13-32. CHOMSKY, N. Knowledge of Language: Its Elements an sophical Transactions of the Royal Society of London cal Sciences. October 1981, vol.295, n. 1077, pp. 2 ? CHOMSKY, N. A Note on the Creative Aspect of Philosophical Review. July 1982, vol. 91, n. EVERAERT, M.B.H., HUYBREGTS, M.A.C and BOCAUUS, J.J. 'Structures, Not Strii' ences In: Trends in Cognitivetscien

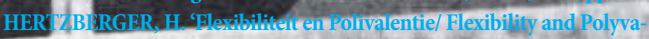
lency'. In Forum. 1962, n. 3, pp. 115-1 TZBERGER, H. 'Identiteit'. In: Forum, 1967, naz, pup 17-18 ZBBRG

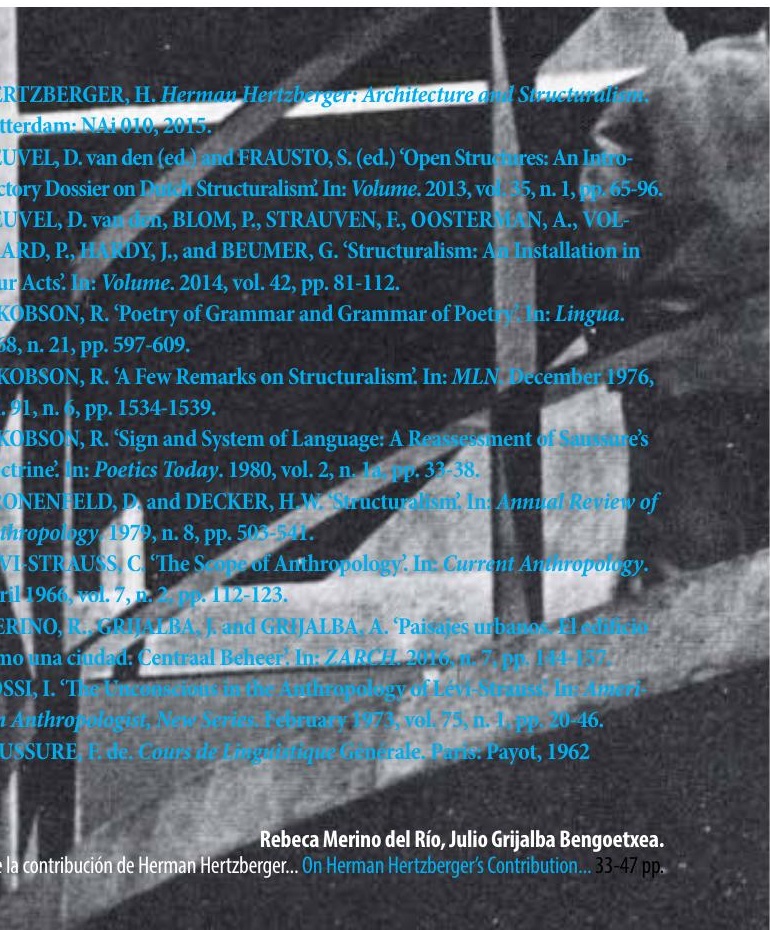


